\title{
Magnaporthe oryzae-Secreted Protein MSP1 Induces Cell Death and Elicits Defense Responses in Rice
}

\author{
Yiming Wang, ${ }^{1,2}$ Jingni Wu, ${ }^{2,3}$ Sang Gon Kim, ${ }^{1}$ Kenichi Tsuda, ${ }^{2}$ Ravi Gupta, ${ }^{4}$ Sook-Young Park, ${ }^{5}$ \\ Sun Tae Kim, ${ }^{4}$ and Kyu Young Kang ${ }^{1,3}$ \\ ${ }^{1}$ Plant Molecular Biology and Biotechnology Research Center, Gyeongsang National University, Jinju, Korea; ${ }^{2}$ Department of \\ Plant Microbe Interactions, Max Planck Institute for Plant Breeding Research, Carl-von-Linne Weg 10, Cologne, 50829, \\ Germany; ${ }^{3}$ Division of Applied Life Science (BK21 program), Gyeongsang National University, Jinju, Korea; ${ }^{4}$ Department of \\ Plant Bioscience, Life and Industry Convergence Research Institute, Pusan National University, Miryang, Korea; and \\ ${ }^{5}$ Korean Lichen Research Institute, Sunchon National University, Suncheon, South Korea
}

Submitted 2 September 2015. Accepted 9 January 2016.

\begin{abstract}
The Magnaporthe oryzae snodprot1 homolog (MSP1), secreted by $M$. oryzae, is a cerato-platanin family protein. msp1-knockout mutants have reduced virulence on barley leaves, indicating that MSP1 is required for the pathogenicity of rice blast fungus. To investigate the functional roles of MSP1 and its downstream signaling in rice, recombinant MSP1 was produced in Escherichia coli and was assayed for its functionality. Application of MSP1 triggered cell death and elicited defense responses in rice. MSP1 also induced $\mathrm{H}_{2} \mathrm{O}_{2}$ production and autophagic cell death in both suspension-cultured cells and rice leaves. One or more protein kinases triggered cell death, jasmonic acid and abscisic acid enhanced cell death, while salicylic acid suppressed it. We demonstrated that the secretion of MSP1 into the apoplast is a prerequisite for triggering cell death and activating defenserelated gene expression. Furthermore, pretreatment of rice with a sublethal MSP1 concentration potentiated resistance to the pathogen. Taken together, our results showed that MSP1 induces a high degree of cell death in plants, which might be essential for its virulence. Moreover, rice can recognize MSP1, resulting in the induction of pathogen-associated molecular pattern-triggered immunity.
\end{abstract}

Magnaporthe oryzae, the causal agent of rice blast disease, is one of the major factors that limits rice productivity. The annual yield loss due to rice blast disease can be up to $30 \%$ of the total rice production. Upon interaction, proteins secreted from both rice and $M$. oryzae determine the fate of their interaction. Fungal secreted effector proteins contribute to its pathogenicity, while rice-derived proteins play crucial roles in the recognition of elicitors and activation of defense responses (Stergiopoulos and de Wit 2009).

Plants have evolved a two-layered immune system, pathogenassociated molecular pattern (PAMP)-triggered immunity (PTI) and effector-triggered immunity (ETI), to fight pathogens (Boyd

Corresponding authors: K. Y. Kang; Telephone: +82-55-772-1961; E-mail: kykang@gnu.ac.kr and S. T. Kim; Telephone: +82-55-350-5505; E-mail: stkim71@pusan.ac.kr

*The $e$-Xtra logo stands for "electronic extra" and indicates that four supplementary figures and one supplementary table are published online.

This article is in the public domain and not copyrightable. It may be freely reprinted with customary crediting of the source. The American Phytopathological Society, 2016. et al. 2013; Tsuda and Katagiri 2010). PAMPs are general elicitors that are recognized by plasma-membrane-localized pattern-recognition receptors (PRR) of plants. This PAMP-PRR interaction is one of the earliest plant-pathogen interactions that trigger PTI. In contrast to PTI, which acts on the extracellular front, ETI is initiated by the cytosolic recognition of speciesspecific pathogen effectors by specific resistance $(R)$ proteins of plants. ETI generates relatively faster and stronger immune responses compared with PTI and results in localized cell death (Khatib et al. 2004; Mateos et al. 1997). Hypersensitive responses (HR) result in death of the cell along with the pathogen therein, thus restricting the ingression of the pathogens to neighboring cells. In plants, cell death is due to autophagy, which involves degradation of the Golgi apparatus, dilation of mitochondria and the endoplasmic reticulum, and nuclear destruction (Singh et al. 2015). Host defense responses, including the production of reactive oxygen species (ROS), nitric oxide bursts, calcium efflux, and hormone production, are associated with autophagic cell death (McDowell and Dangl 2000).

$\mathrm{N}$-acetylchitooligosaccharide (Tanabe et al. 2006) and sphingolipid elicitor (cerebrosides A and C) (Koga et al. 1998) are two well-characterized elicitors from $M$. oryzae that activate the immune response in rice. An elicitor protein, i.e., PemG1 (Qiu et al. 2009), has been reported to activate systemic acquired resistance in plants and is modulated by the salicylic acid (SA) and $\mathrm{Ca}^{2+}$ signaling pathways (Peng et al. 2011). A protein secreted by $M$. oryzae (MoHrip1) has recently been reported to trigger plant defenses (Chen et al. 2012). It was shown that purified MoHrip1 activates early defense signaling in tobacco and enhances rice resistance to $M$. oryzae. Recent studies have shown that several $M$. oryzae-secreted proteins are related to induction of host immune responses and cell death in planta (Chen et al. 2013; Kim et al. 2013). Therefore, characterization of novel fungal elicitors among those secreted proteins would be very useful for understanding $M$. oryzae immune responses in rice.

Proteins of the cerato-platanin (CP) family were first identified in Ceratocystis fimbriata and Moniliophthora perniciosa and are reported to be phytotoxins (Pazzagli et al. 1999; Zaparoli et al. 2009). Large-scale gene expression (RL-SAGE) and proteomics analysis (Chen et al. 2013; Kim et al. 2013) during $M$. oryzae-rice interactions also led to the identification of an array of $\mathrm{CP}$ family proteins. These $\mathrm{CP}$ family proteins induce cell death in tobacco (Pazzagli et al. 1999) and cacao (Zaparoli et al. 2009). Moreover, CP family proteins of Hypocrea atroviridis and Trichoderma virens have been shown to activate the 
host defense system and systemic resistance (Djonović et al. 2006; Seidl et al. 2006). Another CP protein, M. oryzae snodprot1 homolog (MSP1, also called MgSM1), has been reported to be a virulence factor, because the knockout mutants of msp 1 significantly reduce the $M$. oryzae pathogenicity of rice (Jeong et al. 2007). However, ectopic expression of MgSM1 in Arabidopsis showed enhanced broad-spectrum disease resistance against Botrytis cinerea, Alternaria brassicicola, and Pseudomonas syringae pv. tomato (Yang et al. 2009). MgSM1 also triggered systemic acquired resistance against $B$. cinerea and $P$. syringae pv. tomato, indicating that MSP1 can be recognized as an avirulence factor in Arabidopsis (Yang et al. 2009). However, the functional roles of MSP1 causing cell-death phytoxicity and elicitor activity and its downstream signaling in plants remain unclear.

In this study, we report the cellular mechanism of rice cell death and elicitation activity triggered by the $M$. oryzae-secreted
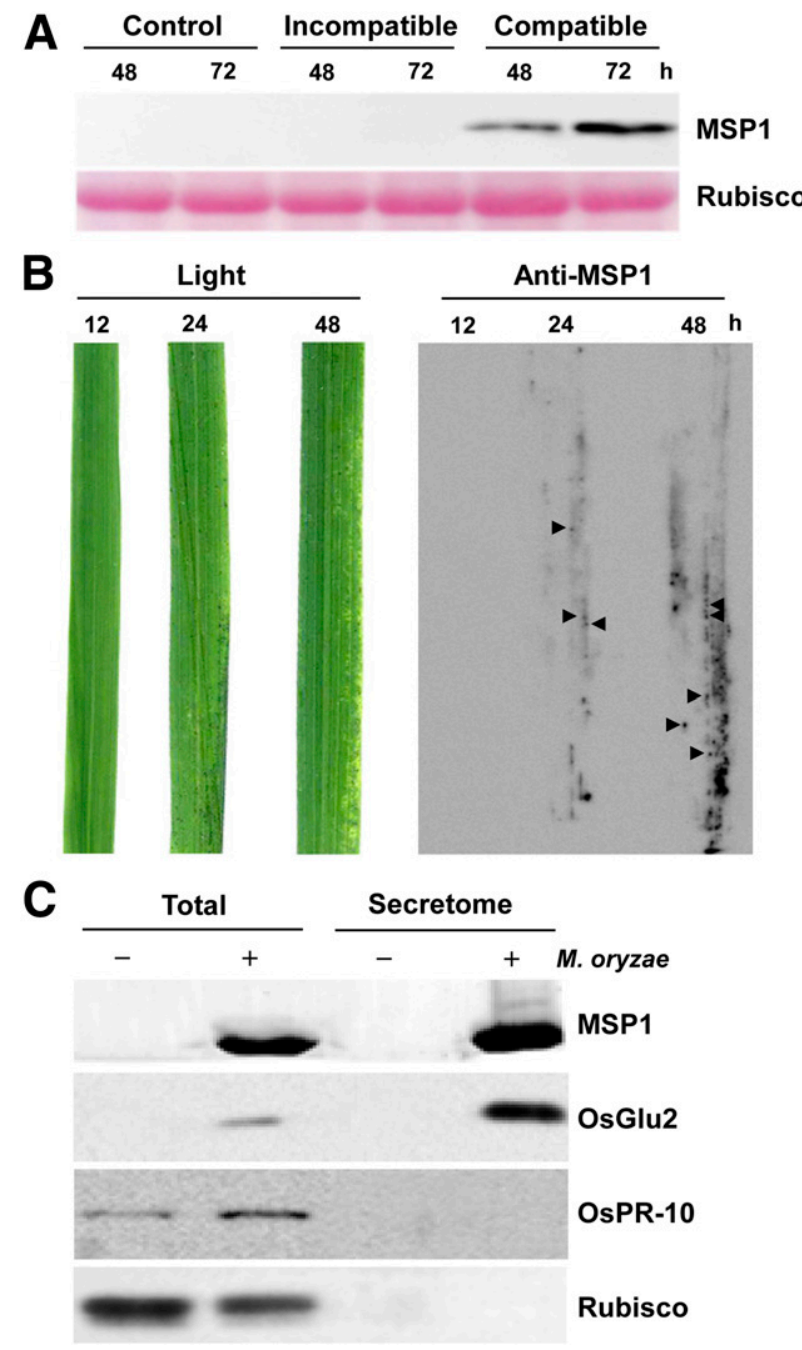

Fig. 1. Expression analysis of MSP1 during rice-Magnaporthe oryzae infection. A, Immunoblotting of MSP1 in the total proteins of uninfected (- M. oryzae) and infected samples $(+M$. oryzae). B, Fungal-infected morphology is shown at left and the MSP1 expression pattern at right (antiMSP1). The arrowheads indicate signals from fungal-infected lesions. $\mathbf{C}$, Western blot analysis of MSP1 in apoplastic fractions. Expression of MSP1, rice apoplectic protein OsGlu2, cytosolic protein OsPR10, and chloroplastic protein $\mathrm{RuBisCO}$ in the total and secreted protein fractions (apoplastic) isolated from uninfected and compatible strain-infected tissues at $72 \mathrm{~h}$ postinoculation. Three independent experiments were performed for each experiment. protein MSP1. Exogenous treatment of rice with recombinant MSP1 resulted in autophagic cell death accompanied by ROS accumulation, ion leakage, and expression of rice defense-related genes. MSP1 was secreted into the apoplast; this apoplastic localization but not cytosolic accumulation was essential for induction of cell death and expression of defense-related genes. In summary, we demonstrated that MSP1 triggers autophagic cell death and elicits host defense responses.

\section{RESULTS}

\section{M. oryzae secretes MSP1 in the host apoplast.}

First, we investigated MSP1 expression during rice-M. oryzae infection, using Western blotting with specific antibodies raised against purified recombinant MSP1. MSP1 expression was detected $12 \mathrm{~h}$ postinoculation (hpi), with further increases at 48 and $72 \mathrm{hpi}$, as the pathogen proliferated in rice leaves, while it was not detected in the noninfected leaves (Fig. 1A). Because MSP1 protein was not detected in incompatible interactions, we used compatible interactions in further studies.

To validate MSP1 secretion according to disease development, a leaf-blotting approach was performed to detect MSP1 protein during fungal infection, and MSP1 was detected in the lesions of diseased rice leaves (Fig. 1B). A high level of MSP1 secretion was confirmed in the rice apoplastic protein fraction along with the rice secretory protein OsGlu2, which was used as a positive marker for defense activation and secretion during in planta infection (Fig. 1C). OsPR-10 and RuBisCO, used as intracellular protein markers, were only detected in the total protein fraction but not in the apoplastic extract, confirming the purity of isolated apoplastic proteins (Fig. 1C). Taken together, these results suggested that MSP1 is induced and secreted into rice apoplasts during infection.

\section{MSP1 induces cell death and elicits defense responses in plants.}

The His-tagged recombinant MSP1, purified from E. coli (Supplementary Fig. S1), exhibited a time- and dose-dependent cell-death activity in both suspension-cultured rice cells (SCCs) derived from cultivar Jinheung and rice leaves (Fig. 2A to E), which was accompanied by $\mathrm{H}_{2} \mathrm{O}_{2}$ accumulation (Fig. $2 \mathrm{~B}$ and D). Ion leakage and $\mathrm{H}_{2} \mathrm{O}_{2}$ production were noted at $0.1-$ to $0.25-\mu \mathrm{M}$ MSP1 treatments, respectively, and at $8 \mathrm{~h}$ posttreatment (hpt) in SCCs. To confirm the cell-death activity of MSP1, PBZ1 promoter::GFP transgenic lines were constructed and MSP1 was applied on nonwounded rice leaves. $P B Z 1$ is a cell-death marker gene (Kim et al. 2008). Cell death and $\mathrm{H}_{2} \mathrm{O}_{2}$ accumulation were observed upon application of $0.5 \mu \mathrm{M}$ MSP1 at $72 \mathrm{hpt}$ (Fig. 2E). Bovine serum albumin (BSA), which was used as a negative control, did not induce any cell-death activity. Moreover, protease K-treated MSP1 did not show any cell-death effect, indicating that cell death was specifically due to the presence of MSP1 protein (Fig. 2E). Semiquantitative polymerase chain reaction (PCR) analysis showed upregulation of WRKY45, Duf 26, PBZ1, PR10, and OsGlu 2 after MSP1 treatment, suggesting that MSP1 treatment activated the plant immune response (Supplementary Fig. S2). Based on these results, it can be concluded that exogenous application of MSP1 triggers cell death and elicits defense responses, including $\mathrm{H}_{2} \mathrm{O}_{2}$ accumulation and defense gene expression in rice.

To understand whether this cell death-inducing ability of MSP1 is specific to rice, we performed an in vitro phytotoxic assay with Nicotiana benthamiana and Arabidopsis (Fig. 3). A strong autofluorescence signal induced by cell death was detected after infiltration of MSP1 in N. benthamiana leaves (Fig. 3A to C). Similarly, application of MSP1 on Arabidopsis leaves 
also triggered cell death, callose deposition (Fig. 3D), and ROS accumulation in the protoplast (Fig. 3E). Defense marker genes, i.e., AtPR1 and PDF1.2, were also induced in Arabidopsis after MSP1 treatment (Fig. 3F). Transgenic plants harboring $P B Z 1$ promoter::GFP and DUF26 promoter::GFP reporters were used to confirm the immune activation by MSP1 in Arabidopsis. The domain of unknown function 26 (DUF26) gene was induced upon $M$. oryzae infection (Kim et al. 2008, 2013) and was used as a marker for immune activation in Arabidopsis (Wu et al. 2014). After treatment with MSP1 protein on leaves without wounding stress, the green fluorescent protein (GFP) signal was detected in the leaves of both transgenic plants (Fig. 3G). In addition, recombinant MSP1 protein-induced cell death was also observed in two japonica-type rice cultivars, Jinheung and Nakdong (varietal background of $P B Z 1$ promoter::GFP transgenic plant), further suggesting that the cell-death activity of MSP1 had no host specificity. Taken together, these results indicated that MSP1 protein induces cell death in different plant species.

\section{MSP1 triggers autophagic programmed cell death (PCD).}

Recombinant MSP1-treated samples showed enlarged and irregular nuclei (Fig. 4A) along with the DNA fragmentation (Fig. 4B) at $48 \mathrm{hpt}$, suggesting that MSP1-induced cell death is mediated by PCD. OsATG4, OsATG8, OsATG10, and PI3K are considered markers for autophagy because these proteins are necessary for vesicle expansion and completion (Hayward et al. 2009). Therefore, reverse transcription (RT)-PCR was performed to investigate the expression patterns of these genes, and the results showed that the expression of OsATG4 and OsATG10b was enhanced early, at $8 \mathrm{hpt}$, followed by PI3K in response to MSP1 treatment (Fig. 4C). These results further suggested that MSP1 activates autophagic pathways that lead to HR-PCD.

Transmission electron microscopy of nontreated SCCs showed intact organelles, including the nucleolus, nucleus, Golgi apparatus, plastids, starch grains, and mitochondria (Fig. 5A to C). However, autophagic cell-death morphology was evident after MSP1 treatment (Fig. 5D to I). No distinct cell organelles were found in MSP1-treated cells, and nuclear degradation and autophagosome structures were observed (Fig. 5D). Small autophagic bodies were observed within the cells (Fig. 5E), nuclei were disintegrated but not condensed, and nuclear envelopes were gathered into a chain-like shape surrounded by an autophagosome (Fig. 5E and F). This large autophagosome was also found within the cells containing small, degraded organelles (Fig. 5G to I). Finally, all organelles merged and adhered to the cell wall (Fig. $5 \mathrm{~J}$ to $\mathrm{L}$ ). These results indicated that MSP1 triggers autophagic death of rice cells.

\section{Protein phosphatase negatively regulates MSP1-induced cell death.}

To understand the biochemical pathways related to MSP1induced cell death in rice, we evaluated the effects of various biochemical inhibitors, such as the protein synthesis inhibitor cycloheximide $(\mathrm{CHX})$ and the protein phosphatase inhibitor okadaic acid (OA), on MSP1-induced cell death of rice SCCs. $\mathrm{CHX}$ treatment suppressed cell death and $\mathrm{H}_{2} \mathrm{O}_{2}$ accumulation, suggesting that protein synthesis is required for signaling (Fig. 6A and $\mathrm{B}$ ). OA treatment markedly enhanced cell death and $\mathrm{H}_{2} \mathrm{O}_{2}$ accumulation (Fig. 6A and $\mathrm{B}$ ), indicating that one or more protein phosphatases are negative regulators of these responses. This finding also suggests that one or more protein kinases are positive regulators of these processes, as reported previously (Rodriguez et al. 2010). Therefore, we investigated the protein kinase activation status in response to MSP1, using an in-gel kinase assay. One or more protein kinases of approximately $48 \mathrm{kDa}$ were found to be activated 30 min after MSP1 treatment (Fig. 6C). Furthermore, OA treatment enhanced and prolonged the kinase activation. These results suggested that one or more protein kinases
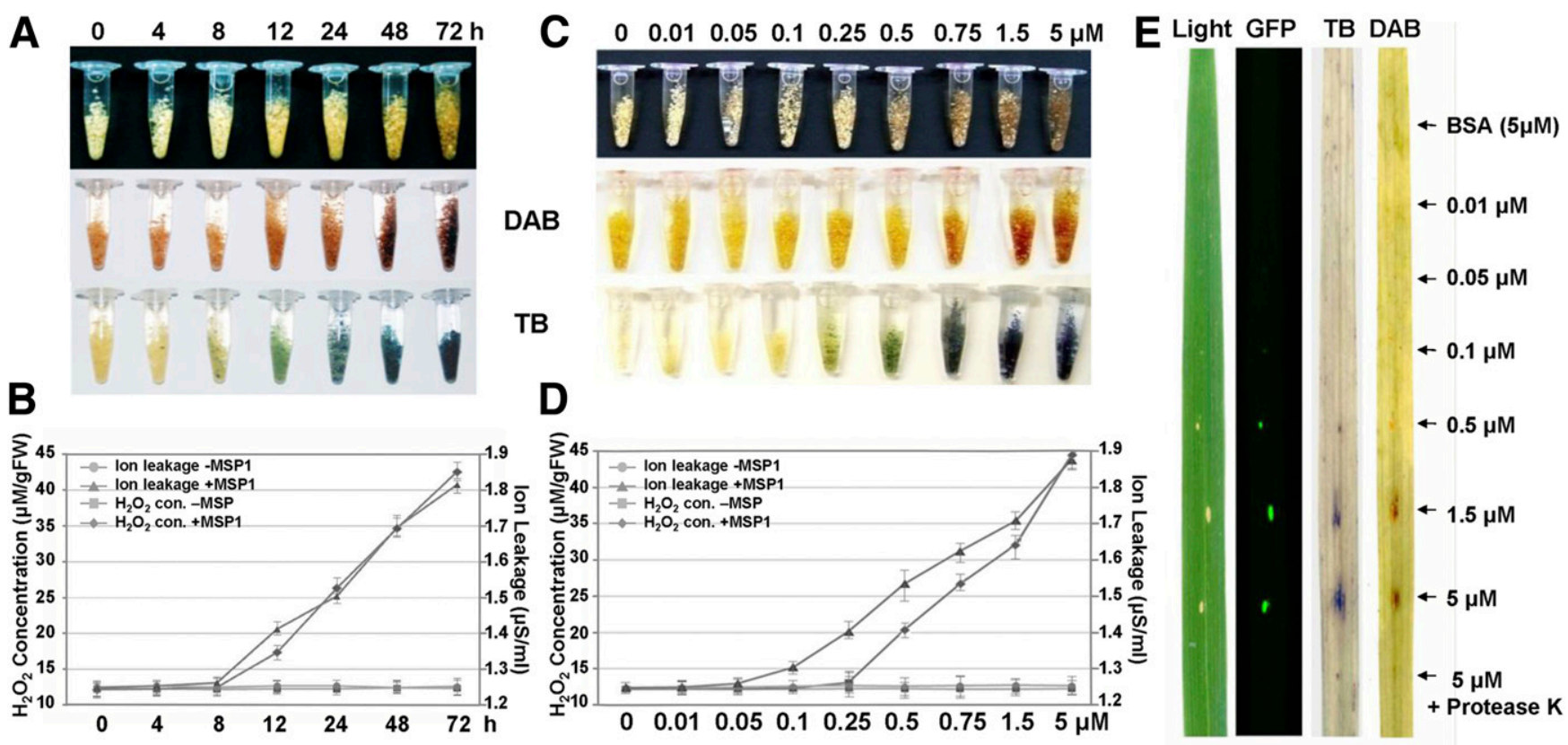

Fig. 2. Cell death and $\mathrm{H}_{2} \mathrm{O}_{2}$ production by recombinant MSP1 protein in suspension-cultured rice cells and leaves. Time dependence at $1 \mu \mathrm{M}$ MSP1 in the medium and dosage dependence at $72 \mathrm{~h}$ posttreatment (hpt) were used for analysis. A and $\mathbf{C}$, Cell-death morphology. 3,3'-Diaminobezidine-(DAB) staining for $\mathrm{H}_{2} \mathrm{O}_{2}$ accumulation and trypan blue (TB)-staining for cell death were detected in a time- and dosage-dependent manner. $\mathbf{B}$ and $\mathbf{D}, \mathrm{H}_{2} \mathrm{O}_{2}$ accumulation (left) and ion leakage (right) in cells after MSP1 treatment. The error bars represent the standard deviations from three biological replicates. E, Cell death and $\mathrm{H}_{2} \mathrm{O}_{2}$ accumulation in response to MSP1 treatment. PBZ1 promoter::GFP rice leaves were treated with various MSP1 dosages. Green fluorescent protein signal, trypan blue staining, and DAB staining were performed at $72 \mathrm{hpt}$. Bovine serum albumin and protease K-treated MSP1 were used as controls. Three independent experiments with each of the five leaves were confirmed. 
mediate the cell-death responses and $\mathrm{H}_{2} \mathrm{O}_{2}$ accumulation triggered by MSP1, whereas one or more protein phosphatases counteracted these processes.

Jasmonic acid (JA) and abscisic acid (ABA) play positive roles in MSP1-induced cell death.

Application of exogenous hormones did not induce cell death or $\mathrm{H}_{2} \mathrm{O}_{2}$ accumulation (Fig. 7A). Cotreatment of JA, and ABA with MSP1 significantly enhanced cell death and $\mathrm{H}_{2} \mathrm{O}_{2}$ accumulation (Fig. 7A and $\mathrm{B}$ ). However, SA slightly suppressed the cell death and $\mathrm{H}_{2} \mathrm{O}_{2}$ accumulation induced by MSP. GFP expression was enhanced by JA in the $P B Z 1$ promoter::GFP transgenic plant upon treatment, even with a $0.1 \mu \mathrm{M}$ MSP1 concentration that was one-fifth of what was needed for cell-death induction (Fig. 7C). These results indicated that $\mathrm{JA}$ and $\mathrm{ABA}$ positively regulated the signaling activated by MSP1.

\section{Apoplastic localization of MSP1 is essential for cell-death activation.}

To understand whether MSP1 induces cell death through ETI- or PTI-type responses in rice, the apoplastic or cytosolic accumulation of MSP1 was investigated. For this purpose, $M S P 1$ was fused with mCherry either without the putative signaling peptide or with the $O s G l u 1$ signaling peptide, and the construct was introduced to $P B Z 1$ promoter::GFPtransgenic plants by particle bombardment. The mCherry signal was detected, while the GFP signal was not detected in the cytosol of rice sheath cells transformed with $M S P 1$ without signal peptides. In contrast, MSP1 with the OsGlu1 signal peptide produced both mCherry and GFP signals (Fig. 8A and B). Western blotting demonstrated that both constructs generated similar MSP1 expression levels regardless of the presence of the signal peptide (Fig. 8C). However, defense-related genes, such as $P B Z 1, P R-10$, and $C u / Z n-S O D$ (superoxide dismutase),
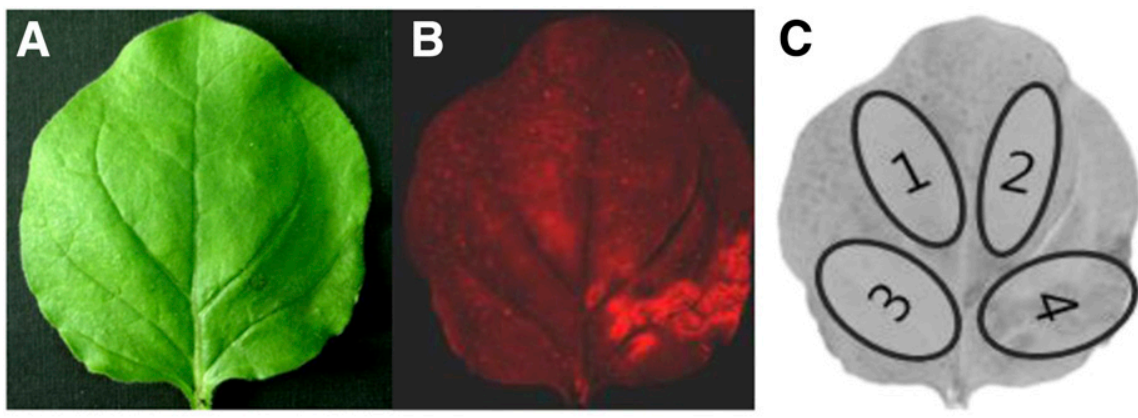
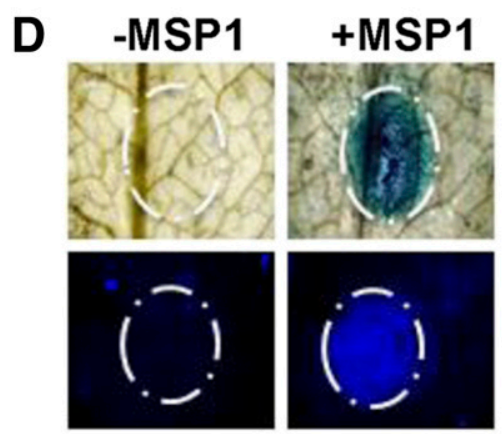

$\mathbf{F}$

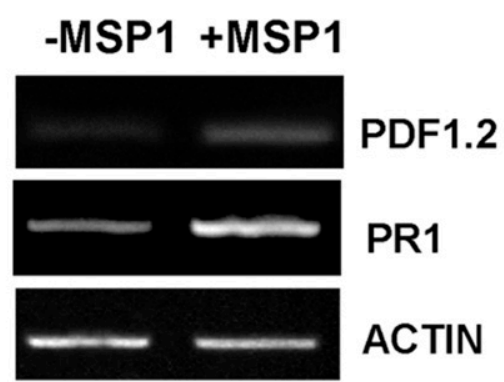

E $\mathrm{H}_{2}$ DCFDA

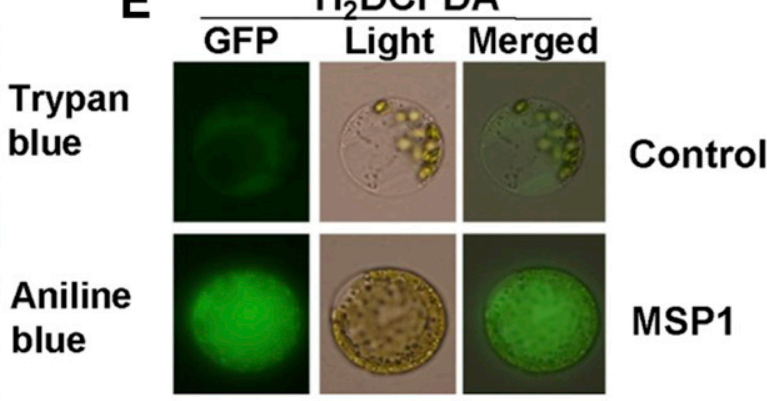

G Dufpro::GFPPBZ1pro::GFP

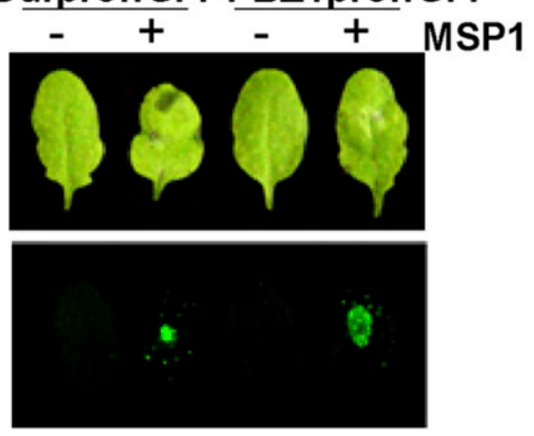

Fig. 3. MSP1 induces cell death and activates defense responses in tobacco and Arabidopsis. A to C, Phototoxic ability of MSP1 in tobacco leaf. MSP1 protein $(100 \mu \mathrm{g} / \mathrm{ml})$ was infiltrated into the leaf (A) and autofluorescence (B) induced by cell death was taken at $48 \mathrm{~h}$ postinfiltration, by LAS-4000 (Fujifilm). C, Area of Nicotiana benthamiana leaf infiltrated with $1.5 \mathrm{mM}$ Tris buffer (1), $50 \mathrm{mM}$ Tris buffer with $100 \mu \mathrm{g}$ of bovine serum albumin per milliliter (2), MSP1 protein incubated with proteinase-K (3), or purified MSP1 protein (4). D, Arabidopsis leaf was coated with MSP1 and was detected with trypan blue and callose deposition at $48 \mathrm{~h}$ posttreatment (hpt). Three independent experiments with each of five leaves were confirmed. E, Accumulation of $\mathrm{H}_{2} \mathrm{O}_{2}$ in $\mathrm{Arabidopsis}$ protoplasts after being treated with MSP1. Arabidopsis protoplasts were treated with $5 \mu \mathrm{g}$ of MSP1 for $12 \mathrm{~h}$ and were stained with 2',7'-dichlorodihydrofluorescein diacetate $\left(\mathrm{H}_{2}\right.$ DCFDA). The DCFDA green fluorescence signal was obtained by fluorescence microscopy. Three independent experiments with each of 20 protoplasts were confirmed. F, Reverse transcription polymerase chain reaction analysis of Arabidopsis defense-related genes. An Arabidopsis leaf after treatment with MSP1 for $24 \mathrm{~h}$ was harvested and the RNA expression levels of PDF1.2 and PR1 were confirmed. G, Activation of green fluorescent protein reporter under the Duf 26 promoter and PBZ1 promoter. MSP1 protein $(5 \mu \mathrm{g})$ was dropped on the surface of Arabidopsis leaves, and signal was detected at 48 hpt. The results were observed from three independent experiments. 
were remarkably expressed only upon introduction of $M S P 1$ with the $O s G l u 1$ signaling peptide (Fig. 8C), indicating that apoplastic localization is a prerequisite to induce cell death and defense-gene activation in rice.

To allow the data to be comparable to a previous study (Jeong et al. 2007), we generated an MSP1 gene-deletion mutant $\Delta m s p 1$ and the complement Msp1c (Supplementary Fig. S3). We observed no significant differences between the wild-type and the mutant $\Delta m s p l$ for any of the pathogenicity-related phenotypes tested. No differences were observed for mycelial growth, conidiation in V8 juice agar, conidial germination, and appressorium formation. Similarly, no differences were observed for virulence in planta. The wild type, $\Delta m s p 1$, and the complement Msplc were highly virulent to cv. Nakdong, with disease indexes of 4 to 5 (maximum of 5), indicating that virulence was not significantly affected. These virulence results are apparently different from those by Jeong et al. (2007), who reported that the $M S P 1$ gene plays a role in disease in $M$. oryzae $70-15$. It was shown that exogenous application of MSP1 could trigger immune activation in plants, which suggests that pretreatment with MSP1 may function as a PAMP inducer to enhance host immune responses against pathogen infection.

To confirm our hypothesis, Oryzae sativa cv. Jinheung was inoculated with the virulent fungal strain $\mathrm{KJ} 301$ with or without pretreatment with a lower dosage level of MSP1 $(0.1 \mu \mathrm{M}$, equivalent to one-fifth of the minimal cell-death induction) $12 \mathrm{~h}$ before pathogen challenge. This sublethal MSP1 treatment had no visible detrimental effect and did not induce cell death in leaves at 72 hpi (Fig. 9A). Few lesions were detected in MSP1pretreated leaves after challenge with KJ301, but brown celldeath spots (HR) were observed (Fig. 9A). However, lesions were evident on $M$. oryzae $\mathrm{KJ} 301-$ infected leaves. mRNA levels of the autophagy-related gene ATG4 and the PR genes Duf 26, $\mathrm{Cu} / \mathrm{Zn}$-SOD, and $P R 10$ were enhanced by the exogenous application of MSP1 (Fig. 9B). Moreover, expression levels of these genes were further increased when challenged with KJ301 than

A

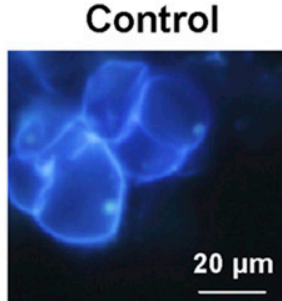

+ MSP1

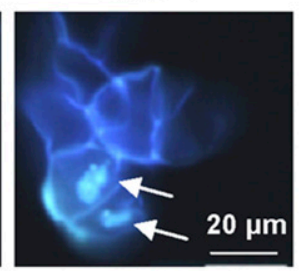

B

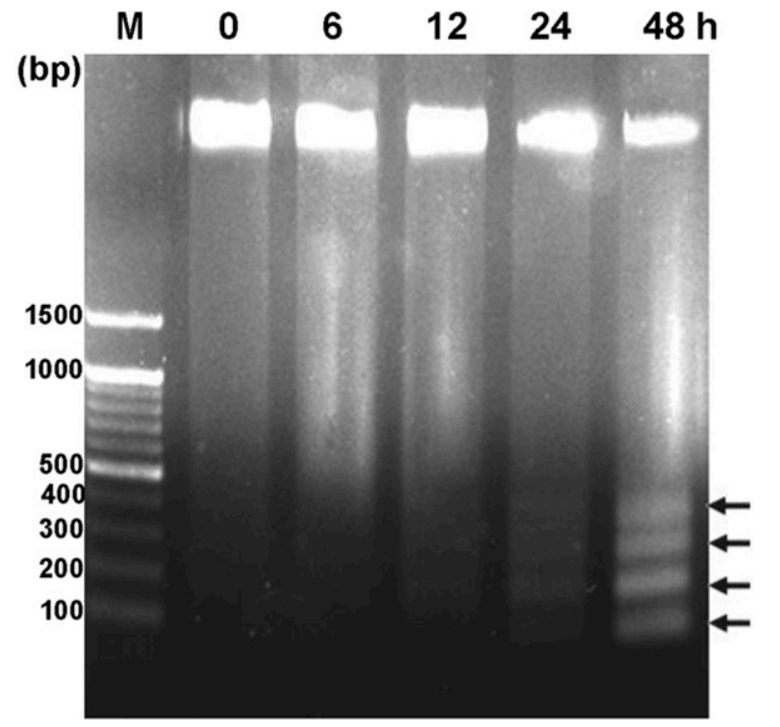

C
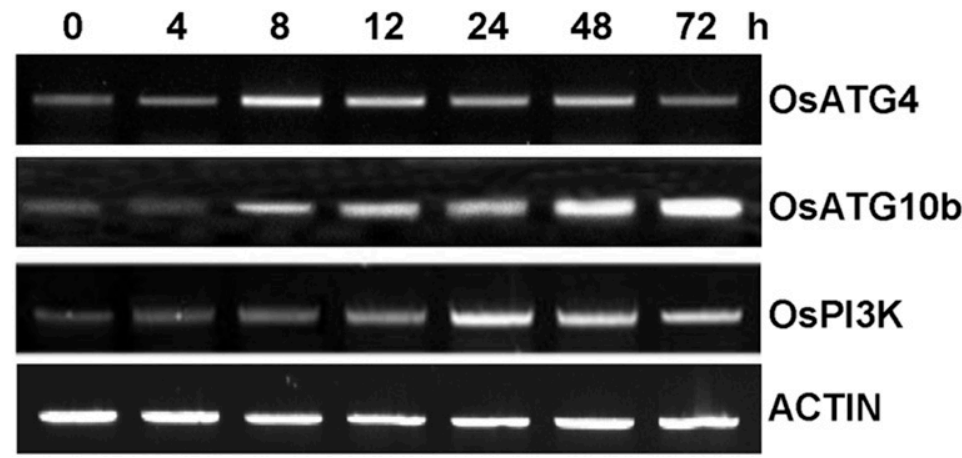

Fig. 4. MSP1 triggered programmed cell death (PCD) in suspension-cultured rice cells. A, Nuclear morphology with or without MSP1 treatment at 48 h posttreatment (hpt) was detected by fluorescence microscopy after 4',6-diamidino-2-phenylindole staining. Three independent experiments for 20 cells each were confirmed. B, DNA fragmentation was detected after MSP1 $(1 \mu \mathrm{M})$ treatment. The arrows indicate fragmented DNA at 48 hpt. C, Semiquantitative polymerase chain reaction analysis of PCD-related genes in response to MSP1 treatment. The results were observed from three independent experiments. 
with KJ301 alone (Fig. 9B). These results indicated that pretreatment with sublethal MSP1 concentration potentiates an early and sustained HR-PCD response, which enhances the ability of the host to counteract the fungal infection.

\section{DISCUSSION}

Snodprot proteins are members of the cerato-platanin family and have been identified in a diverse group of fungi. MSP1 is a small protein of about $12 \mathrm{kDa}$ that is secreted from $M$. oryzae (Jeong et al. 2007). The $M S P 1$ gene deletion mutant $\Delta m s p 1$, generated from $M$. oryzae 70-15, exhibited reduced virulence on susceptible rice cultivars and barley seedlings. The results also showed that recombinant MSP1 protein, approximately $400 \mathrm{ng}$, applied on wounded barley leaves was unable to trigger cell death (Jeong et al. 2007). However, the mechanism of action of MSP1 remained largely elusive. In this study, we focused on a combination of molecular and biochemical approaches to better understand the involvement of MSP1 in rice cell death and its downstream signaling in rice. We provide several lines of evidence that MSP1 is secreted by M. oryzae into the rice apoplast at the time of infection and causes cell death in rice.

The gene deletion mutant $\Delta m s p l$ was generated from the $\Delta \mathrm{Ku} 70$ deletion mutant of the M. oryzae strain Guy11 (Kershaw and Talbot 2009) and complementation fungal mutants to confirm the role of MSP1 on $M$. oryzae pathogenicity-related phenotypes. Unlike a previous study (Jeong et al. 2007), no significant differences were observed between wild-type and deletion mutant $\Delta m s p 1$ in all the pathogenicity-related phenotypes including virulence. This discrepancy might be due to not only $M$. oryzae strain specificity but also differences in one or both the cultivar and host.

At first, we detected the secretion of MSP1 from rice at $12 \mathrm{hpi}$ of $M$. oryzae, using Western blotting and leaf blot assays. MSP1 accumulation was not detected during incompatible interactions
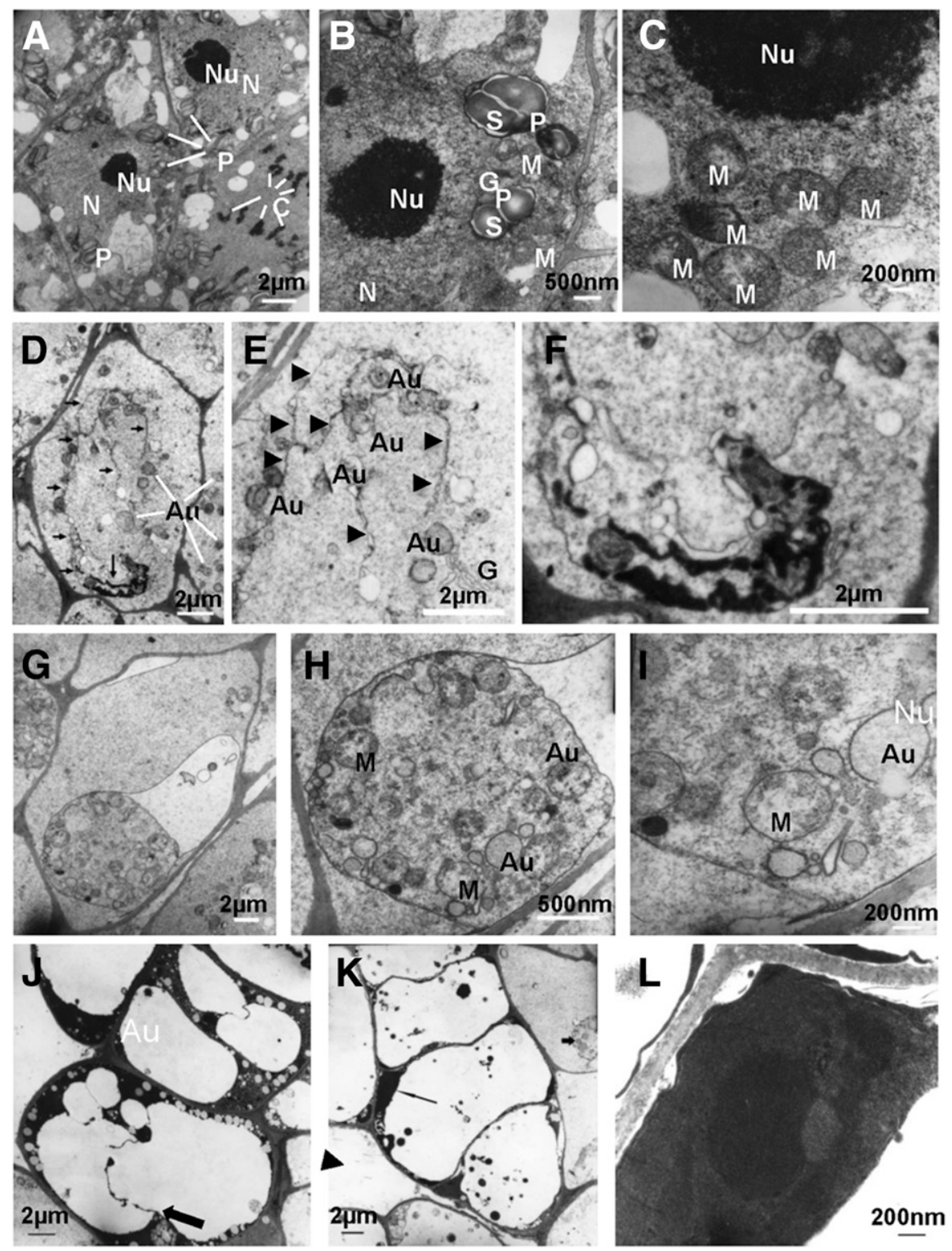

Fig. 5. Transmission electron microscopy of autophagy formation in suspension-cultured rice cells. A to C, Organelle morphology in control callus cells without MPS1 treatment. D to I, Autophagy and nuclear degradation in MSP1-treated cells at 48 posttreatment. J to $\mathbf{L}$, Aggregation of cellular components during late-stage cell death. $\mathrm{Nu}=$ nucleolus, $\mathrm{N}=$ nucleus, $\mathrm{P}=$ plastid, $\mathrm{C}=$ chromosome, $\mathrm{S}=$ starch grain, $\mathrm{M}=$ mitochondria, $\mathrm{G}=\mathrm{Golgi}$ apparatus, and $\mathrm{Au}=$ autophagosome. The arrowheads in E indicate the chain-like shape of nuclear envelopes; the arrowheads in K indicate the autophagy in programmed cell death (PCD) cells; the arrow in J indicates the shrunken cell organelles in late-stage PCD cells. These results were observed from three independent experiments. 
but only in the susceptible interactions. The early cell death (hypersensitive response) with the incompatible interactions led to a suppression of fungal growth, which may cause protein degradation. Therefore, no signal from MSP1 was detected by Western blot analysis. Previously, it was shown that MSP1 protein is secreted into an in vitro culture medium and is not associated with M. oryzae cell walls (Jeong et al. 2007). Consistently, we observed a high level of accumulation of MSP1 in rice apoplasts after infection with $M$. oryzae, which suggested that MSP1 is secreted even in in planta conditions. MSP1 showed a time- and dose-dependent cell death in rice. Moreover, this cell death effect of recombinant MSP1 was not restricted to rice only, as MSP1 also induced cell death in Arabidopsis, tobacco, and different cultivars of rice. However, a previous report showed that recombinant MSP1 protein was unable to trigger cell death in barley leaves, likely because the wounding treatment in phytotoxicity assays with $400 \mathrm{ng}$ of MSP1 might not be an optimal method or the concentration did not induce cell death, although the authors also reported that treatment of culture filtrate from $\mathrm{N}$-starved fungi caused limited necrosis of rice tissue (Jeong et al. 2007). Here, cell-death assays using rice SCCs and leaves
(Figs. 2, 7, and 8) clearly indicated that cell death and defense gene activation were highly induced when MSP1 was treated on nonwounding rice tissue because the signal was strongly transduced through the outer membrane in host apoplasts. The celldeath effect of $\mathrm{CP}$ family proteins was shown previously in cacao (Lombardi et al. 2013; Meinhardt et al. 2014; Zaparoli et al. 2009). Furthermore, ectopic expression of MSP1 in Arabidopsis also induced local hypersensitive reactions (Yang et al. 2009).

We also observed that cell death was accompanied by $\mathrm{H}_{2} \mathrm{O}_{2}$ accumulation. It is well-known that ROS, such as $\mathrm{H}_{2} \mathrm{O}_{2}$, induce cell death and serve as cell-death signals during stress responses (Bestwick et al. 1997; Van Breusegem and Dat 2006). Moreover, $\mathrm{H}_{2} \mathrm{O}_{2}$ produced during an oxidative burst also acts as a trigger for programmed cell death (PCD) in plants (Levine et al. 1994; Singh et al. 2015).

To identify the cellular mechanism underlying MSP1-induced cell death in rice, we investigated morphological, biochemical, and cellular biological features of rice SCCs after $48 \mathrm{~h}$ of MSP1 treatment, which is a valid time point to observe cell death. Nuclear degradation, DNA fragmentation, and autophagosome formation are the key features of PCD in plant cells (Singh et al.

A

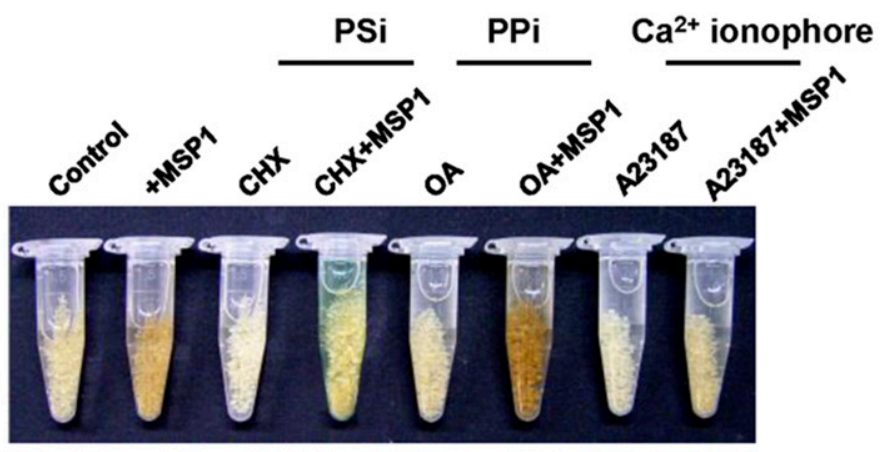

B

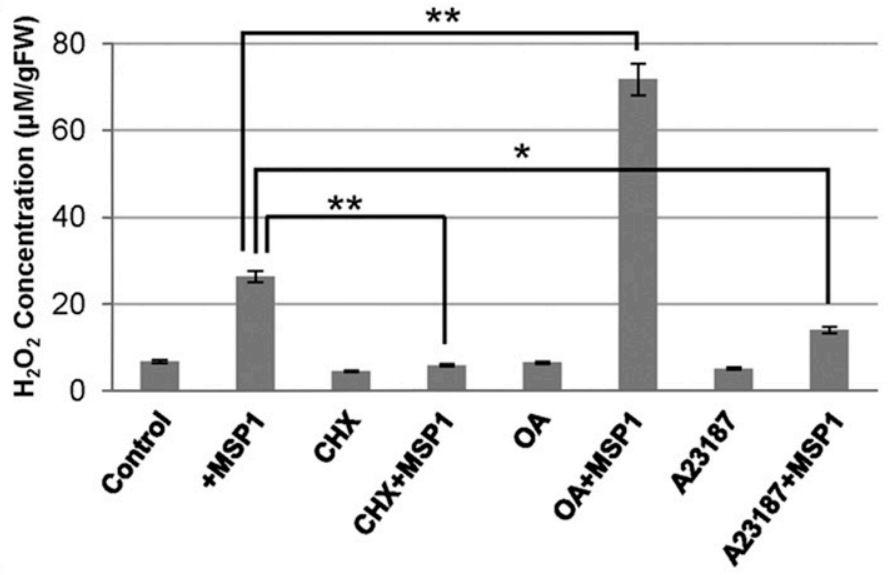

C
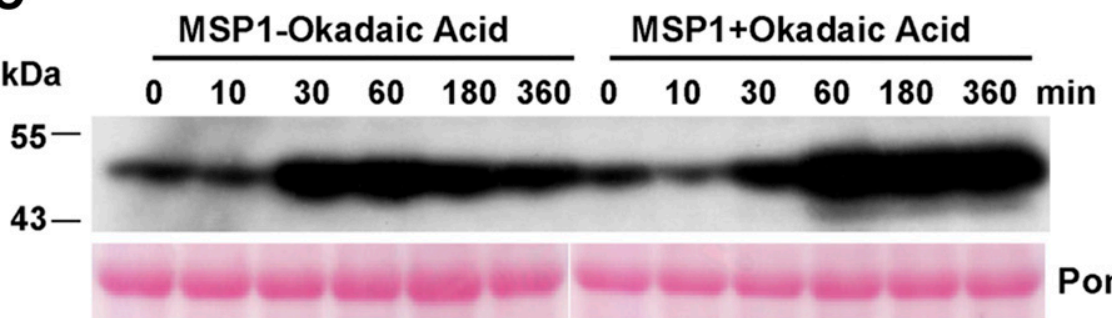

\section{Ponceau S}

Fig. 6. Regulation of MSP1-activated cell death by biochemical inhibitors. A, Cell-death morphology of rice suspension-cultured cells after treatment with 0.5 $\mu \mathrm{M}$ MSP1 and $1 \mu \mathrm{M}$ of the protein synthesis inhibitor (PSi) cycloheximide (CHX), protein phosphatase inhibitor (PPi) okadaic acid (OA), and 20 mM of calcium ionophore A23187 at 72 posttreatment. $\mathbf{B}, \mathrm{H}_{2} \mathrm{O}_{2}$ measurement in the corresponding samples. The bars represent the standard deviations from three independent experiments. One asterisk (*) indicates significant difference by Student's $t$ test at $P<0.05$; two asterisks $(* *)$ indicate $P<0.01$. C, OA suppressed the switching off of kinase activity as determined by in-gel kinase activity assay. 
2015); therefore, all of these parameters were analyzed after MSP1 treatment. The results showed that MSP1-induced cell death was mediated by autophagy. Autophagy is a prerequisite for induction of HR-PCD and is associated with vacuolar cell death (Liu et al. 2005; van Doorn 2011). OsATG4, OsATG8, OsATG10, and PI3K are necessary for vesicle expansion and completion, and their expression indicates autophagy (Hayward et al. 2009). Here, we observed upregulation of all these genes, suggesting that MSP1-induced cell death is mediated by autophagy. In plants, regulation of $\mathrm{PCD}$ via the autophagy pathway is controversial. One autophagy gene, BECLIN1, together with other genes, contributes to the suppression of PCD during $R$ gene- and non- $R$ gene-mediated resistance in tobacco (Liu et al. 2005). In contrast, in Arabidopsis, the bacterial effector AvrRps4-triggered PCD is associated with autophagy (Hofius et al. 2009). However, Yoshimoto et al. (2009) reported that autophagy negatively regulates immune-related PCD. Thus, the autophagy pathway appears to play opposite roles (pro- and anti-cell death) depending on the situation. Nevertheless, autophagy is associated with and contributes positively to the cell death triggered by MSP1.

Phytohormones play critical roles in plant defenses (Tsuda and Somssich 2015). JA and ABA induce $P R$ gene expression in rice SCCs, which was antagonized by SA (Kim et al. 2003). In this study, we observed that MSP1 regulation is mediated by JA and ABA. It has been reported that SA potentiates cell death and $\mathrm{H}_{2} \mathrm{O}_{2}$ accumulation during ETI (Shirasu et al. 1997). Surprisingly, MSP1-induced cell death and $\mathrm{H}_{2} \mathrm{O}_{2}$ accumulation in rice were suppressed by SA (Fig. 7A and B), suggesting differential roles of SA during ETI and MSP1-triggered immunity. Alternatively, SA might play a different role in the death of rice cells.
Typically, PAMPs in apoplastic regions are recognized by the receptors located at the plasma membrane of plants, while pathogen-derived effector molecules trigger defense responses after recognition by cytoplasmic receptors. $\mathrm{CP}$ acts as a virulence factor in many plant species (Jeong et al. 2007; Pazzagli et al. 1999; Zaparoli et al. 2009). Moreover, secretion of MSP1 from $M$. oryzae induces rapid cell death in rice. Moreover, application of MSP1 to the rice leaves resulted in the enhanced expression of plant defense genes. Previously, it was shown that ectopic expression of the $M$. grisea $\mathrm{CP}$ gene $M g S M 1$ resulted in the upregulation of $P R-1, P R-5$, and $P D F 1.2$ genes and triggered the local hypersensitivity reactions in Arabidopsis (Meinhardt et al. 2014; Yang et al. 2009).

These results clearly demonstrated that apoplastic localization of MSP1 is a prerequisite for triggering the defense response, and uptake of MSP1 into cytosol is not necessary for cell-death activation. These results indicated that MSP1 is recognized in the outer plasma membrane region and induces PTI in rice. Moreover, as phosphatase inhibitor (OA) treatment enhances MSP1-induced cell death, it can be speculated that MSP1 would be recognized by a leucine-rich repeat protein kinase and its phosphorylation would mediate cell death and defense responses. However, this possibility requires further investigation.

In summary, we here provide new evidence for a cellular mechanism of $M$. oryzae MSP1 protein on host cell death. MSP1 protein is secreted into rice apoplasts, in which it is recognized in the rice outer membrane and triggers autophagic PCD and PTI. It is evident from our results that MSP1 could also trigger rapid immune responses (Figs. 2, 6, 7, 8, and 10) and PCD (Figs. 3 and 4) in rice. Therefore, we hypothesize that early exposure of

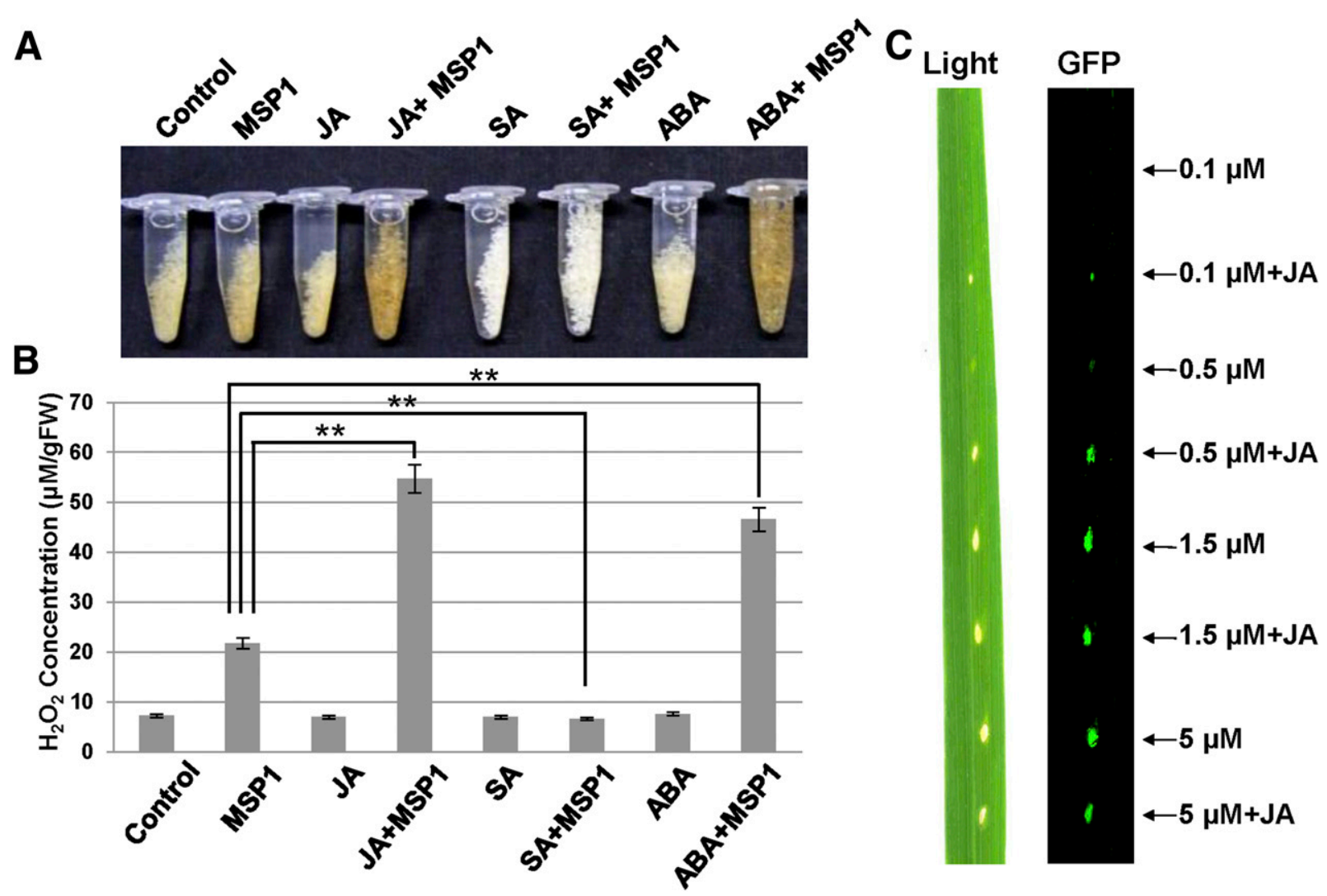

Fig. 7. Phytohormone regulation of MSP1-activated cell-death signaling. A, Cell-death morphology of suspension-cultured rice cells treated with $250 \mu \mathrm{M}$ jasmonic acid (JA), $5 \mathrm{mM}$ salicylic acid (SA), and $200 \mu \mathrm{M}$ of abscisic acid (ABA), or hormone coupled with $0.5 \mu \mathrm{M}$ MSP1 at 72 posttreatment (hpt). B, $\mathrm{H}_{2} \mathrm{O}_{2}$ accumulation after treatment. The bars represent the means and standard deviations of three independent experiments. Asterisks (**) indicate significant difference by Student's $t$ test at $P<0.01$. C, Cell death and green fluorescent protein (GFP) expression in $P B Z 1$ promoter::GFP rice leaf was detected after treatment with $0.1,0.5,1.5$, or $5 \mu \mathrm{M}$ MSP1 with or without $250 \mu \mathrm{M}$ JA at 72 hpt. Three independent experiments with five detached leaves in each experiment were performed. 
MSP1 on rice acts as an avirulence factor. The MSP1-induced signal might be transduced through one or more protein kinases and mediated through the phytohormones JA and ABA (Fig. 10). Furthermore, pretreatment with a low MSP1 concentration on rice leaves does not trigger cell death but protects plants against pathogen invasion by potentiating defense responses. Taken together with our identification of a short active region of MSP1 as an inducer of the defense response, our findings suggest that MSP1 could be applied in the field to enhance the resistance of rice to the devastating pathogen $M$. oryzae.

\section{MATERIALS AND METHODS}

Preparation of plant and fungal materials.

Arabidopsis (Col-0) and $N$. benthamiana were grown in a controlled environmental chamber at $23^{\circ} \mathrm{C}$ under a 14-h light photoperiod. Rice seeds of wild-type (Oryzae sativa L. cvs. Jinheung and Nakdong) and transgenic rice plants harboring $P B Z 1$ promoter::GFP (Kim et al. 2008) were sterilized in $70 \%$ (vol/vol) ethanol for $5 \mathrm{~min}$ and $3 \%$ (vol/vol) sodium hypochlorite for $30 \mathrm{~min}$, followed by extensive washing in sterilized water. After inhibition at $4^{\circ} \mathrm{C}$ for 2 days in the dark, seeds were planted in standard soil and were grown under natural light conditions in a greenhouse $\left(20\right.$ to $\left.30^{\circ} \mathrm{C}\right)$ for up to four- to five-leaf stages for treatment or particle bombardment.

Strains M. oryzae KJ301 and KJ401 were used for compatible and incompatible interactions to Oryza sativa cv. Jinheung, respectively (Kim et al. 2013). The $\Delta K U 70$ mutant strain was provided by N. J. Talbot (University of Exter, U.K.) and was used for MSP1 gene deletion mutants.

\section{Preparation of SCCs.}

Sterilized dehulled seeds (cv. Jinheung) were imbibed in $4^{\circ} \mathrm{C}$ for $24 \mathrm{~h}$, were placed in N6 medium, and were cultured in the
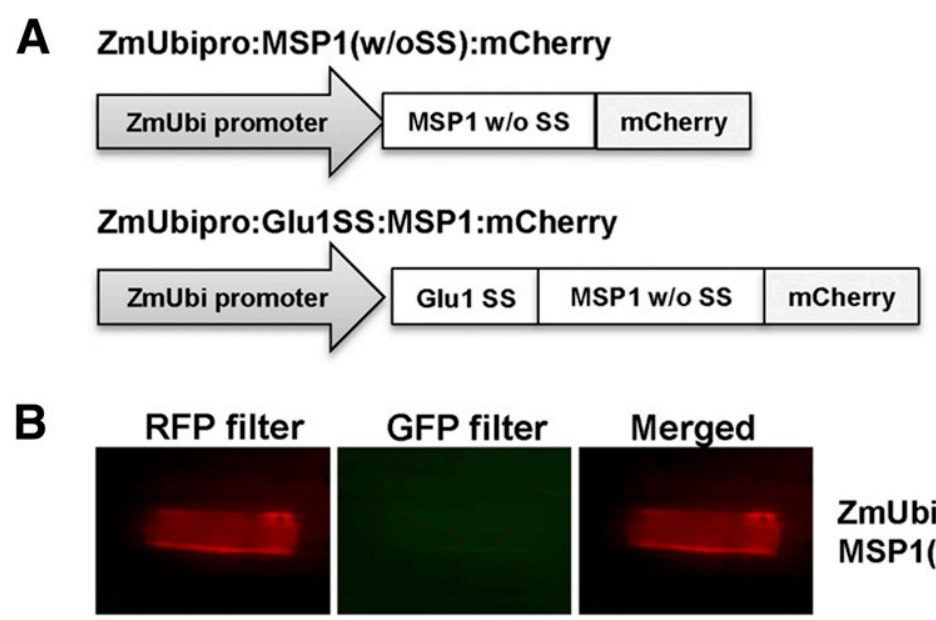

ZmUbipro:

MSP1(w/oss):Cherry
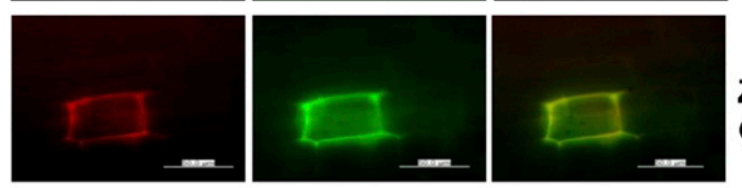

ZmUbipro:

Glu1SS:MSP1:Cherry

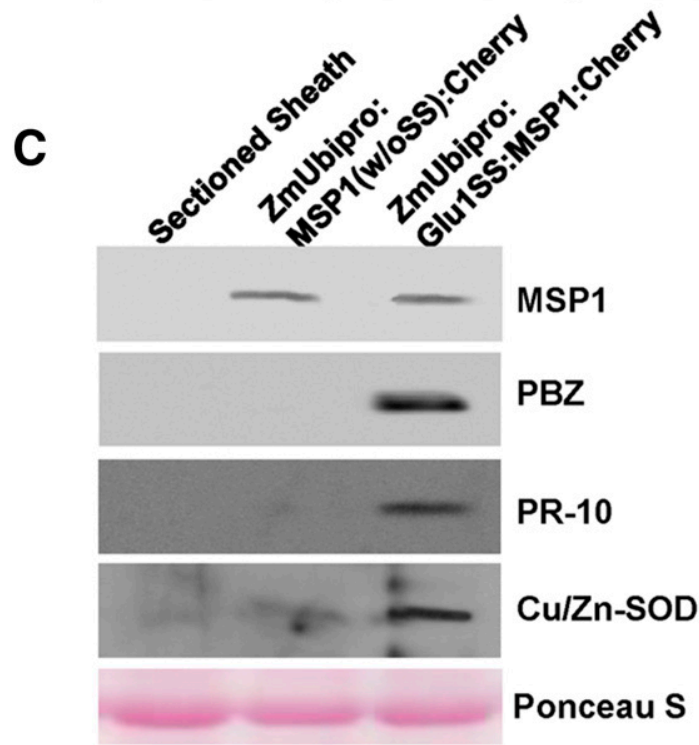

Fig. 8. Transient expression of secretory and nonsecretory MSP1 constructs in PBZ1 promoter::GFP-transfected rice leaf-sheath cells. A, Schematic of two vector constructs used for transient gene expression. Glu1 SS = glucanase signal sequence. B, Confocal microscopy detection of mCherry and green fluorescemt protein (GFP) signals after transient expression in rice sheath cells after $48 \mathrm{~h}$. The activation of $P B Z 1$ promoter was confirmed in at least 20 independent cells in three independent experiments. C, Expression of MSP1 and rice defense-related PBZ1, PR-10, and Cu/Zn-SOD (superoxide dismutase) in total proteins isolated from sectioned sheath, leaf sheath cells transiently expressing MSP1 were detected by Western blot analysis. 
dark at $25^{\circ} \mathrm{C}$ to induce callus formation. Induced calli were subcultured at weekly intervals in N6 suspension medium with shaking at $120 \mathrm{rpm}$. SCCs were treated with MSP1 two to three days following subculture in fresh medium.

\section{Cloning, expression, purification, and antibody generation} of MSP1.

Total RNA from $M$. oryzae was isolated using the Oligotex mRNA maxi kit (Qiagen, Valencia, CA, U.S.A.), and cDNA was synthesized using the SuperScript III cDNA synthesis kit (Invitrogen, Carlsbad, CA, U.S.A.). The MSP1 gene without the signal sequence was amplified by PCR, using oligonucleotide primers containing MSP1-BamHI-F and MSPl-HindIII-R sites (Supplementary Table S1). The PCR product was cleaned and cloned into the pGEM-T Easy vector (Promega, Madison, WI, U.S.A.); cloning was confirmed by sequencing. The insert was digested with BamHI and HindIII, was subcloned into the
pQE30a vector (Qiagen), and was transformed into E. coli XL-1 blue. Expression of the recombinant protein was induced by the addition of $1 \mathrm{mM}$ isopropyl- $\beta$-D-thiogalactoside when the culture reached an optical density at $600 \mathrm{~nm}$ of 0.6 ; the culture was continued for $6 \mathrm{~h}$. E. coli cells were harvested by centrifugation at $5,000 \times g$ for $10 \mathrm{~min}$ at $4^{\circ} \mathrm{C}$. The pellet was resuspended in lysis buffer $\left(8 \mathrm{M}\right.$ urea, $10 \mathrm{mM}$ Tris, and $100 \mathrm{mM} \mathrm{NaH}{ }_{2} \mathrm{PO}_{4}, \mathrm{pH}$ 8.0 ), and the recombinant protein was purified per the manufacturer's instructions (Qiagen). The denatured protein was dialyzed stepwise at $4^{\circ} \mathrm{C}$ in $10 \mathrm{mM}$ Tris buffer with 6,4 , and $2 \mathrm{M}$ urea and, then, twice with $10 \mathrm{mM}$ Tris buffer. Recombinant MSP1 (200 $\mu \mathrm{g}$ of each) was used for immunizing the rabbits to raise the antibodies, as described previously (Kim et al. 2003).

\section{Chemical treatment and toxin activity tests.}

Solutions of CHX $(1 \mu \mathrm{M})$, OA $(1 \mu \mathrm{M})$, and A23187 $(20 \mu \mathrm{M})$ were prepared in $0.01 \%$ dimethylsulfoxide and were incubated
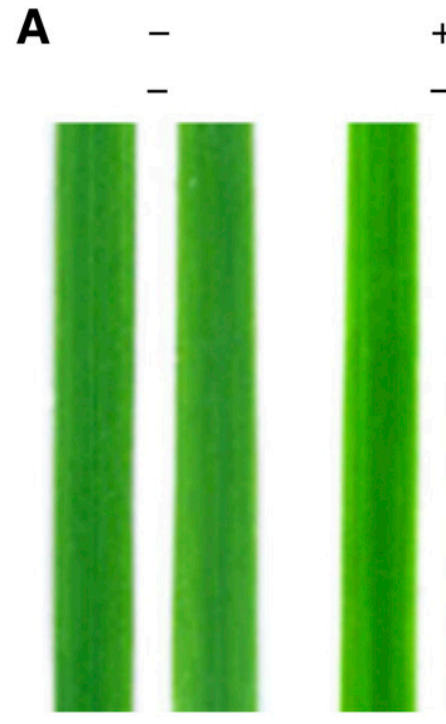

B
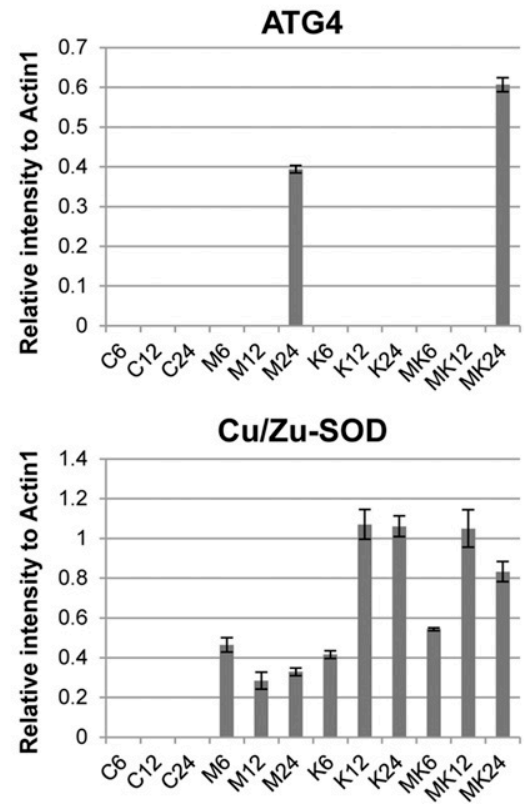

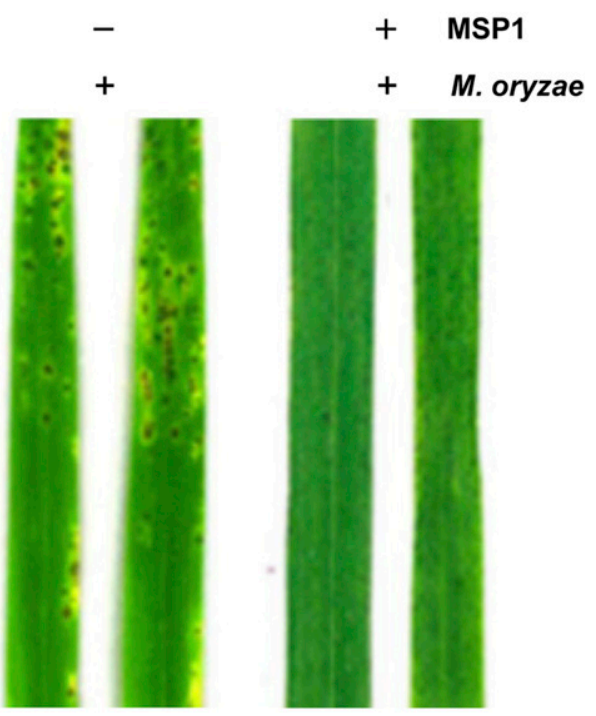

Duf26

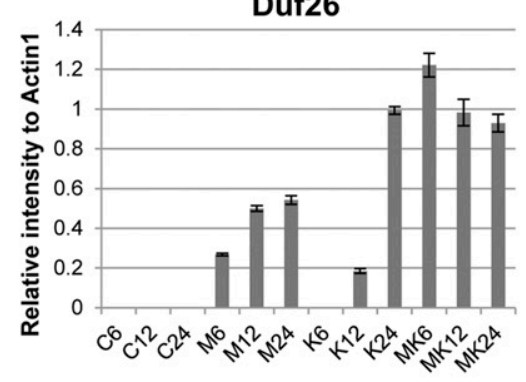

PR10

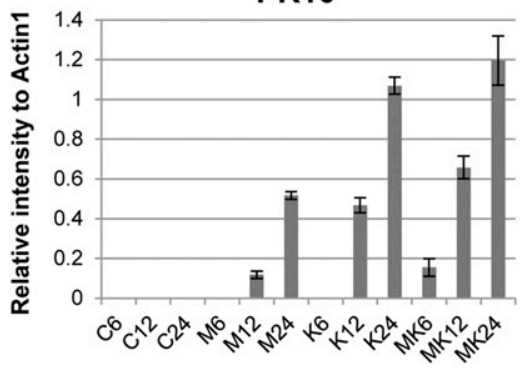

Fig. 9. MSP1 potentiates early host immunity to suppress fungal infection. A, Disease symptoms of rice infected with a virulent Magnaporthe oryzae strain (KJ301) with or without 12-h pretreatment with recombinant MSP1 $(0.1 \mu \mathrm{M})$. The fungal infection phenotypes were confirmed with at least 20 leaves from three independent experiments. B, mRNA levels of defense-related genes. C6, C12, and C24 = water-treated leaf at at 6, 12, and $24 \mathrm{~h}$ postinoculation, respectively; M = MSP1-treated leaf, K = KJ301-treated leaf, MK = MSP1- and KJ301-treated leaf. The bars represent the means and standard deviations of three independent experiments. 
with the SCCs for $1 \mathrm{~h}$ before treatment with fungal elicitor. Phytohormones with the following concentrations were used for the experiment: JA $(250 \mu \mathrm{M}), \mathrm{SA}(5 \mathrm{mM})$, or ABA $(200 \mu \mathrm{M})$. For toxin activity tests on leaves, $10 \mu \mathrm{l}$ of solution including chemicals and MSP1 protein in $0.01 \%$ Tween-20 was applied on the leaf surface without wounding stress; $0.01 \%$ Tween was set as a negative control in the leaf treatment.

\section{Semiquantitative RT-PCR.}

RNA isolation and first-strand cDNA synthesis was performed as described above. A mixture comprising $500 \mathrm{ng}$ of mRNA, $500 \mathrm{ng}$ of Oligo dT18, and $500 \mu \mathrm{M}$ dNTP was prepared at $65^{\circ} \mathrm{C}$ and was chilled on ice. The following reagents were added to the mixture to the respective final concentrations: $1 \times$ first-strand buffer, $5 \mathrm{mM}$ dithiothreitol (DTT), 2 units RNaseOUT per microliter, and 10 units SuperScript II RT enzyme per microliter. The mixture was incubated at $50^{\circ} \mathrm{C}$ for $60 \mathrm{~min}$ and was inactivated at $70^{\circ} \mathrm{C}$ for $15 \mathrm{~min}$. PCR was performed on a PTC-0220 PCR machine (MJ Research, Waltham, MA, U.S.A.), using synthesized cDNA as a template. Gene-specific primers were designed from the coding sequence of the desired gene. An equal amount of cDNA was used for each PCR reaction by normalization to the actin gene.

\section{Particle bombardment.}

MSP1 without signal sequence was fused with the mCherry sequence at the C-terminal by PCR. Then, $60 \mathrm{bp}$ of the $O$. sativa signal sequence of the glucanase 1 (Glul) gene was added to the
$\mathrm{N}$ terminal (ATG GCA AAG CAT GGC GTT GCT TCC GTT TTA ACA CTG GCA TTG GTC CTT GGA GTT GCG GCC). The MSP1::mCherry and GluSP::MSP1::mCherry sequences were then ligated into the pDONR 221 Gateway vector and sequences were confirmed. For transient expression, the sequences were ligated into the pIPKb002 vector, which contains a hygromycinresistance marker under the control of a maize ubiquitin promoter (Himmelbach et al. 2007) by means of the LR reaction. Four or five leaf-stage rice sheaths were cut into sections $2 \mathrm{~cm}$ long and $0.4 \mathrm{~mm}$ deep using a single-layer blade and were placed on halfstrength Murashige Skoog medium for $1 \mathrm{~h}$ at $28^{\circ} \mathrm{C}$ in the dark, before particle bombardment.

All bombardments were conducted using a Biolistic PDC1000/He system (Bio-Rad, Hercules, CA, U.S.A.). M-17 tungsten particles $(3 \mathrm{mg}$ ) were washed once with $100 \%$ ethanol, twice with sterile distilled water, and were resuspended in $50 \mathrm{ml}$ of water. Plasmid DNA ( $8 \mathrm{mg}$ ) followed by $20 \mathrm{ml}$ of spermidine $(0.1 \mathrm{M})$ and $40 \mathrm{ml}$ of calcium chloride $(2.5 \mathrm{M})$ were added to the tungsten particles. The particles were spun down and were washed with $200 \mathrm{ml}$, followed by $100 \mathrm{ml}$ of $100 \%$ ethanol. Finally, the tungsten particles were resuspended in $20 \mathrm{ml}$ of $100 \%$ ethanol, were dropped onto a macrocarrier, and were airdried. Each sample was bombarded twice at 1,100 psi in a 23- to 30-in $\mathrm{Hg}$ vacuum (Ueki et al. 2009) and was documented after $48 \mathrm{~h}$.

\section{Protein extraction, Western blot, and leaf blot.}

Control and treated samples were harvested and pulverized in liquid nitrogen. Samples were then homogenized with protein

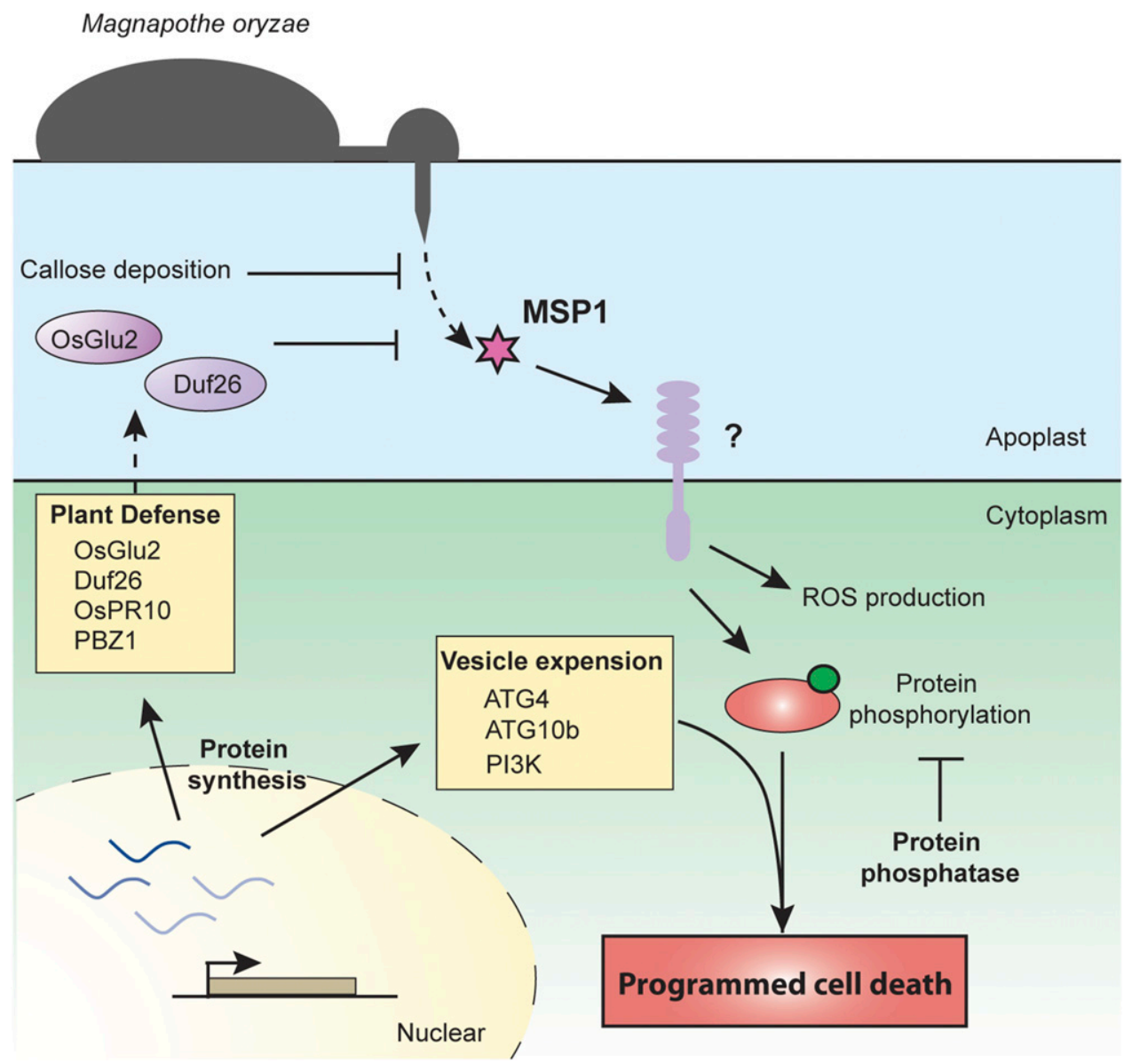

Fig. 10. Proposed model for MSP1 induced signaling in rice. During infection, Magnaporthe oryzae secretes MSP1 in the rice apoplast and it binds to a yetunknown membrane receptor. The binding of MSP1 with the receptor may induce kinase activity, which could further lead to the phosphorylation of unknown proteins. The downstream signaling that might be induced by this phosphorylation event would lead to a $\mathrm{H}_{2} \mathrm{O}_{2}$ burst and ultimately programmed cell death. This also activates the expression of pathogenesis-related proteins, which are involved in defense against pathogen attack. 
extraction buffer (0.5 M Tris-Cl [pH 8.3], 2\% [vol/vol] NP-40, $20 \mathrm{mM} \mathrm{MgCl}$, $1 \mathrm{mM}$ phenyl methyl sulfonyl fluoride, $2 \%$ [vol/vol] $\beta$-mercaptoethanol) and proteins were extracted using phenol-methanolic ammonium acetate precipitation, as described previously (Kim et al. 2013). Apoplastic proteins were isolated, as described previously (Wang et al. 2014). Briefly, fungalinfected rice leaves were incubated in buffer $\left(200 \mathrm{mM} \mathrm{CaCl}_{2}\right.$, $5 \mathrm{mM}$ Na-acetate, $\mathrm{pH} 4.3$ ) for $1 \mathrm{~h}$ on ice with gentle shaking. Proteins from the extraction buffer were extracted by phenolmethanolic ammonium acetate precipitation. For Western blotting, proteins $(20 \mu \mathrm{g})$ were resolved on sodium dodecyl sulfatepolyacrylamide gel electrophoresis (SDS-PAGE) and were transferred to a polyvinylidene diflouride membrane using a semidry electrophoretic apparatus (Hoefer, Holliston, MA, U.S.A.). Protein detection was performed using anti-MSP1, OsPR10, OsGlu2, and PBZ1 $(1: 10,000)$ and anticytochrome-c, GFP, His-Tag, and a RuBisCo large subunit $(1: 5,000)$ as primary antibodies and antirabbit or antimouse $(1: 10,000)$ conjugated with horseradish peroxidase as secondary antibodies.

For leaf blotting, infected fresh leaf tissue was blotted on a nitrocellulose membrane using a Bio-Rad model 785 vacuum blotter for $2 \mathrm{~h}$. Signals in the blotted membrane were then detected as described above.

\section{DNA fragmentation assay.}

After grinding the callus samples in liquid nitrogen, DNA extraction buffer ( $6 \mathrm{M}$ urea, $0.35 \mathrm{M} \mathrm{NaCl}, 100 \mathrm{mM}$ Tris- $\mathrm{Cl}[\mathrm{pH}$ 7.6], $1 \mathrm{mM}$ EDTA, 2\% [wt/vol] SDS) was added to the samples and was incubated at room temperature for $30 \mathrm{~min}$. The buffer layer was collected after centrifugation at $10,000 \times g$ for $10 \mathrm{~min}$ at $4^{\circ} \mathrm{C}$. An equal volume of phenol/chloroform/isoamyl alcohol $(25: 24: 1, \mathrm{vol} / \mathrm{vol} / \mathrm{vol})$ was then added, followed by centrifugation at $12,000 \mathrm{rpm}$ for $10 \mathrm{~min}$. The upper layer was collected and was again extracted with chloroform. DNA was precipitated by adding 2.5 volumes of ethanol containing a $1 / 10$ volume of $4 \mathrm{M}$ sodium acetate. Genomic DNA was collected by centrifugation at $12,000 \mathrm{rpm}$ for $15 \mathrm{~min}$ after incubation at $-20^{\circ} \mathrm{C}$ for $1 \mathrm{~h}$. After air drying, DNA was dissolved in $100 \mu \mathrm{l}$ of Tris-EDTA buffer. The samples were subjected to electrophoresis on $1.5 \%$ agarose gels, and the DNA was stained with ethidium bromide.

\section{Transmission electron microscopy.}

Calli were fixed in $2 \%$ (vol/vol) glutaraldehyde in $50 \mathrm{mM}$ phosphate-buffered saline ( $\mathrm{pH} 6.8$ ) at $4^{\circ} \mathrm{C}$ for $24 \mathrm{~h}$, followed by postfixation in $1 \% \mathrm{OsO}_{4}$ buffer at $4{ }^{\circ} \mathrm{C}$ overnight. Samples were then sequentially dehydrated through a 50 to $100 \%$ ethanol series, were embedded in Epons-812 resin, and were polymerized at $60^{\circ} \mathrm{C}$ for $48 \mathrm{~h}$. Ultrathin $(70 \mathrm{~nm})$ sections were cut using an Ultracut microtome (EM UC6; Leica, Wetzlar, Germany). The ultrathin sections were mounted on slides and were then stained with uranyl acetate followed by lead citrate for imaging, using a Philips Tecnai 12 transmission electron microscope.

\section{In-gel kinase activity assay.}

Protein samples were incubated at $60^{\circ} \mathrm{C}$ for $10 \mathrm{~min}$ and were separated on a SDS-PAGE gel containing $0.1 \mathrm{mg}$ of MBP per milliliter. The gel was washed three times with $25 \mathrm{mM}$ Tris$\mathrm{HCl}(\mathrm{pH} 7.5), 0.5 \mathrm{mM}$ DTT, $0.1 \mathrm{mM} \mathrm{Na} \mathrm{VO}_{4}, 5 \mathrm{mM} \mathrm{NaF}$, $0.5 \mathrm{mg}$ of BSA per milliliter, and $0.1 \%$ (vol/vol) Triton X-100 for $30 \mathrm{~min}$. The in-gel kinase activity was detected in $25 \mathrm{mM}$ Tris- $\mathrm{HCl}$ (pH 7.5), $1 \mathrm{mM}$ DTT, $0.1 \mathrm{mM} \mathrm{Na}_{3} \mathrm{VO}_{4}$, and $5 \mathrm{mM}$ $\mathrm{NaF}$ at $4^{\circ} \mathrm{C}$. The gel reaction was in $25 \mathrm{mM}$ Tris- $\mathrm{HCl}(\mathrm{pH} 7.5)$, $1 \mathrm{mM}$ DTT, $2 \mathrm{mM}$ EGTA, $12 \mathrm{mM} \mathrm{MgCl}_{2}$, and $0.1 \mathrm{mM}$ $\mathrm{Na}_{3} \mathrm{VO}_{4}$, containing $250 \mathrm{nM}$ ATP and $50 \mu \mathrm{Ci}\left[\gamma^{32} \mathrm{P}\right]$ ATP. After $1.5 \mathrm{~h}$, the reaction was stopped by the addition of $5 \%$ ( $\mathrm{vol} / \mathrm{vol})$ trichloroacetic acid and 1\% (vol/vol) sodium pyrophosphate. The dried SDS-PAGE gel was then exposed to X-Omart film.

\section{Trypan blue and 3,3' -diaminobenzidine (DAB) staining.}

Rice callus and leaves were submerged in a $65^{\circ} \mathrm{C}$ trypan blue solution (2.5 mg of trypan blue per milliliter, $25 \%$ (wt/vol) lactic acid, $23 \%$ water-saturated phenol, $25 \%$ glycerol, and $\mathrm{H}_{2} \mathrm{O}$ for $10 \mathrm{~min}$ and, then, were boiled for $2 \mathrm{~min}$ and left for staining overnight. After destaining in chloral hydrate solution $\left(2.5 \mathrm{~g} \mathrm{ml}^{-1}\right.$ in $\left.\mathrm{H}_{2} \mathrm{O}\right)$ for 3 days, samples were equilibrated with $70 \%$ (vol/vol) glycerol for microscopy. For DAB staining, samples were infiltrated with $1 \mathrm{mg}$ of $\mathrm{DAB}$ per milliliter at $28^{\circ} \mathrm{C}$ for $4 \mathrm{~h}$ in the dark and were then cleaned with $10 \%$ (vol/vol) lactic acid. For leaf tissue, the stained samples were washed in $80 \%$ ( $\mathrm{vol} / \mathrm{vol})$ ethanol until all chlorophyll was removed.

\section{$\mathrm{H}_{2} \mathrm{O}_{2}$ quantification.}

For intracellular $\mathrm{H}_{2} \mathrm{O}_{2}$ quantification, the Amplex Red hydrogen peroxide/peroxidase assay kit (Invitrogen) was used. Treated callus samples were powdered, using liquid nitrogen and, then, equal amounts of each sample were incubated with $50 \mu \mathrm{M}$ Amplex Red reagent and $0.1 \mathrm{U}$ horseradish peroxidase per milliliter at $28^{\circ} \mathrm{C}$ for $30 \mathrm{~min}$ in the dark. A 100 - $\mu$ l volume was used per reaction. A fluorescence microplate reader was used to detect signals, with emission at approximately $590 \mathrm{~nm}$ and absorbance at approximately $560 \mathrm{~nm}$.

\section{Confocal microscopy.}

For detection of mCherry and GFP fluorescence signals in transient-expressed leaf sheath cells, fungal conidia, and fungalinfected leaf-sheath epidermal cells, a laser-scanning microscope (Olympus FV1000) was used. Microscopy images of mCherry and GFP were generated at excitation:emission wavelengths of $543 / 587$ to $625 \mathrm{~nm}$ and $488 / 510$ to $540 \mathrm{~nm}$, respectively.

\section{Disruption of MSP1, complementation,} and phenotype assay.

Based on the sequences at the locus MGG_05344T0 in the Magnaporthe comparative genomics database, the $5^{\prime} 1.3-\mathrm{kb}$ and $3^{\prime}$ 1.4-kb flanking regions of the gene were amplified, using primers MSP1_5'UF_KpnI and MSP1_5'UR_XhoI and primers and MSP1_3'DF_HindIII and MSP1_3'DR_SpeI, respectively, from genomic DNA of $\Delta 70$ mutants. The $2.1-\mathrm{kb}$ hygromycin $\mathrm{B}$ phosphotransferase (HPH) marker cassette was amplified from pBCATPH (Seo et al. 2007), using primers Hyg B_F_XhoI and Hyg B_R_HindIII. These three amplicons were cloned into a pGEM T Easy vector system I (Promega). All clones were verified by sequencing. The mutant allele was cloned into pBC SK+ (Invitrogen) after clones were digested with an appropriate enzyme combination, the $5^{\prime} 1.3-\mathrm{kb}$ flanking region digested with $K p n I$ and XhoI, the 2.1-kb HPH cassette digested with XhoIHindIII, or the 3' 1.4-kb flanking region digested with HindIII and SpeI. The resulting clone was introduced to $\Delta 70$ protoplasts, as previously described (Sweigard et al. 1992). Resulting transformants were selected on TB3 agar medium amended with $150 \mathrm{~g}$ of hygromycin twice and were screened by PCR. Transformants carrying the expected gene deletion mutants were genetically purified via single conidium isolation. Deletion of the MSPl gene was confirmed by DNA gel-blot hybridization analysis, and the loss of MSP1 transcripts was confirmed by RT-PCR.

$\Delta m s p l$ complementation was achieved by amplifying a 3.3$\mathrm{kb}$ fragment containing the $M S P 1$ open reading frame, and $1.3-\mathrm{kb}$ of the $5^{\prime}$ and $1.4-\mathrm{kb}$ of the $3^{\prime}$ flanking regions from wildtype $\Delta 70$ genomic DNA, using primers MSP1_5'UF_KpnI and MSP1_3'DR_SpeI. The purified 3.3-kb complementation construct was cotransformed with the gene in fragments into $\Delta m s p 1$ protoplasts. Putative complemented transformants 
were selected on TB3 plates amended with 800 ppm geneticin (G418 sulfate). After genetic purification by single conidium isolation, complements were confirmed by $M S P 1$ gene expression through RT-PCR.

Infection assays on rice seedlings and pathogenicity-related phenotypes were conducted as previously described (Kim et al. 2009). Statistical analyses were performed using SPSS software v.18.0 (SPSS Inc., Chicago).

\section{ACKNOWLEDGMENTS}

This work was supported by grants from the National Research Foundation of Korea (NRF) funded by the Ministry of Education, Science, and Technology (NRF-2012R1A1A2040584), and Next-Generation BioGreen 21 Program (Plant Molecular Breeding Center, PJ011038), Rural Development Administration, Republic of Korea. We thank J.-Y. Kim (Gyeongsang National University, Jinju, Korea) for supplying the mCherry-pRSET-B vector.

\section{LITERATURE CITED}

Bestwick, C. S., Brown, I. R., Bennett, M. H., and Mansfield, J. W. 1997 Localization of hydrogen peroxide accumulation during the hypersensitive reaction of lettuce cells to Pseudomonas syringae pv phaseolicola. Plant Cell 9:209-221.

Boyd, L. A., Ridout, C., O’Sullivan, D. M., Leach, J. E., and Leung, H. 2013. Plant-pathogen interactions: Disease resistance in modern agriculture. Trends Genet. 29:233-240.

Chen, M., Zeng, H., Qiu, D., Guo, L., Yang, X., Shi, H., Zhou, T., and Zhao, J. 2012. Purification and characterization of a novel hypersensitive response-inducing elicitor from Magnaporthe oryzae that triggers defense response in rice. PLoS One 7:e37654.

Chen, S., Songkumarn, P., Venu, R. C., Gowda, M., Bellizzi, M., Hu, J., Liu, W., Ebbole, D., Meyers, B., Mitchell, T., and Wang, G. L. 2013. Identification and characterization of in planta-expressed secreted effector proteins from Magnaporthe oryzae that induce cell death in rice. Mol. Plant-Microbe Interact 26:191-202.

Djonović, S., Pozo, M. J., Dangott, L. J., Howell, C. R., and Kenerley, C. M 2006. Sm1, a proteinaceous elicitor secreted by the biocontrol fungus Trichoderma virens induces plant defense responses and systemic resistance. Mol. Plant-Microbe Interact 19:838-853.

Hayward, A. P., Tsao, J., and Dinesh-Kumar, S. P. 2009. Autophagy and plant innate immunity: Defense through degradation. Semin. Cell Dev. Biol. 20:1041-1047.

Himmelbach, A., Zierold, U., Hensel, G., Riechen, J., Douchkov, D., Schweizer, P., and Kumlehn, J. 2007. A set of modular binary vectors for transformation of cereals. Plant Physiol. 145:1192-1200.

Hofius, D., Schultz-Larsen, T., Joensen, J., Tsitsigiannis, D. I., Petersen, N. H., Mattsson, O., Jørgensen, L. B., Jones, J. D., Mundy, J., and Petersen, M. 2009. Autophagic components contribute to hypersensitive cell death in Arabidopsis. Cell 137:773-783.

Jeong, J. S., Mitchell, T. K., and Dean, R. A. 2007. The Magnaporthe grisea snodprot1 homolog, MSP1, is required for virulence. FEMS (Fed. Eur. Microbiol. Soc.) Microbiol. Lett. 273:157-165.

Kershaw, M. J., and Talbot, N. J. 2009. Genome-wide functional analysis reveals that infection-associated fungal autophagy is necessary for rice blast disease. Proc. Natl. Acad. Sci. U.S.A. 106:15967-15972.

Khatib, M., Lafitte, C., Esquerré-Tugayé, M.-T., Bottin, A., and Rickauer, M. 2004. The CBEL elicitor of Phytophthora parasitica var. nicotianae activates defence in Arabidopsis thaliana via three different signalling pathways. New Phytol. 162:501-510.

Kim, S., Park, S. Y., Kim, K. S., Rho, H. S., Chi, M. H., Choi, J., Park, J., Kong, S., Park, J., Goh, J., and Lee, Y. H. 2009. Homeobox transcription factors are required for conidiation and appressorium development in the rice blast fungus Magnaporthe oryzae. PLoS Genet. 5:e1000757.

Kim, S. G., Wang, Y., Lee, K. H., Park, Z. Y., Park, J., Wu, J., Kwon, S. J., Lee, Y. H., Agrawal, G. K., Rakwal, R., Kim, S. T., and Kang, K. Y. 2013. In-depth insight into in vivo apoplastic secretome of riceMagnaporthe oryzae interaction. J. Proteomics 78:58-71.

Kim, S. T., Cho, K. S., Yu, S., Kim, S. G., Hong, J. C., Han, C. D., Bae, D. W., Nam, M. H., and Kang, K. Y. 2003. Proteomic analysis of differentially expressed proteins induced by rice blast fungus and elicitor in suspension-cultured rice cells. Proteomics 3:2368-2378.

Kim, S. T., Kim, S. G., Kang, Y. H., Wang, Y., Kim, J. Y., Yi, N., Kim, J. K., Rakwal, R., Koh, H. J., and Kang, K. Y. 2008. Proteomics analysis of rice lesion mimic mutant (spl1) reveals tightly localized probenazoleinduced protein (PBZ1) in cells undergoing programmed cell death J. Proteome Res. 7:1750-1760.

Koga, J., Yamauchi, T., Shimura, M., Ogawa, N., Oshima, K., Umemura, K., Kikuchi, M., and Ogasawara, N. 1998. Cerebrosides A and C, sphingolipid elicitors of hypersensitive cell death and phytoalexin accumulation in rice plants. J. Biol. Chem. 273:31985-31991.

Levine, A., Tenhaken, R., Dixon, R., and Lamb, C. 1994. $\mathrm{H}_{2} \mathrm{O}_{2}$ from the oxidative burst orchestrates the plant hypersensitive disease resistance response. Cell 79:583-593.

Liu, Y., Schiff, M., Czymmek, K., Tallóczy, Z., Levine, B., and DineshKumar, S. P. 2005. Autophagy regulates programmed cell death during the plant innate immune response. Cell 121:567-577.

Lombardi, L., Faoro, F., Luti, S., Baccelli, I., Martellini, F., Bernardi, R., Picciarelli, P., Scala, A., and Pazzagli, L. 2013. Differential timing of defense-related responses induced by cerato-platanin and cerato-populin, two non-catalytic fungal elicitors. Physiol. Plant. 149:408-421.

Mateos, F. V., Rickauer, M., and Esquerré-Tugayé, M. T. 1997. Cloning and characterization of a cDNA encoding an elicitor of Phytophthora parasitica var. nicotianae that shows cellulose-binding and lectin-like activities. Mol. Plant-Microbe Interact 10:1045-1053.

McDowell, J. M., and Dangl, J. L. 2000. Signal transduction in the plant immune response. Trends Biochem. Sci. 25:79-82.

Meinhardt, L. W., Costa, G. G., Thomazella, D. P., Teixeira, P. J. Carazzolle, M. F., Schuster, S. C., Carlson, J. E., Guiltinan, M. J., Mieczkowski, P., Farmer, A., Ramaraj, T., Crozier, J., Davis, R. E., Shao, J., Melnick, R. L., Pereira, G. A., and Bailey, B. A. 2014 Genome and secretome analysis of the hemibiotrophic fungal pathogen, Moniliophthora roreri, which causes frosty pod rot disease of cacao: Mechanisms of the biotrophic and necrotrophic phases. BMC Genomics 15:164.

Pazzagli, L., Cappugi, G., Manao, G., Camici, G., Santini, A., and Scala, A 1999. Purification, characterization, and amino acid sequence of ceratoplatanin, a new phytotoxic protein from Ceratocystis fimbriata f. $\mathrm{sp}$. platani. J. Biol. Chem. 274:24959-24964.

Peng, D. H., Qiu, D. W., Ruan, L. F., Zhou, C. F., and Sun, M. 2011. Protein elicitor PemG1 from Magnaporthe grisea induces systemic acquired resistance (SAR) in plants. Mol. Plant-Microbe Interact 24: 1239-1246.

Qiu, D., Mao, J., Yang, X., and Zeng, H. 2009. Expression of an elicitorencoding gene from Magnaporthe grisea enhances resistance against blast disease in transgenic rice. Plant Cell Rep. 28:925-933.

Rodriguez, M. C. S., Petersen, M., and Mundy, J. 2010. Mitogen-activated protein kinase signaling in plants. Annu. Rev. Plant Biol. 61:621-649.

Seidl, V., Marchetti, M., Schandl, R., Allmaier, G., and Kubicek, C. P. 2006. Epl1, the major secreted protein of Hypocrea atroviridis on glucose, is a member of a strongly conserved protein family comprising plant defense response elicitors. FEBS J. 273:4346-4359.

Seo, B., Kim, H., Lee, Y., and Yun, S. 2007. Functional analysis of a histidine auxotrophic mutation in Gibberella zeae. Plant Pathol. J. 23: 51-56.

Shirasu, K., Nakajima, H., Rajasekhar, V. K., Dixon, R. A., and Lamb, C. 1997. Salicylic acid potentiates an agonist-dependent gain control that amplifies pathogen signals in the activation of defense mechanisms. Plant Cell 9:261-270.

Singh, S., Ambastha, V., Levine, A., Sopory, S. K., Yadava, P. K., Tripathy, B. C., and Tiwari, B. S. 2015. Anhydrobiosis and programmed cell death in plants: Commonalities and differences. Curr. Plant Biol. 2:12-20.

Stergiopoulos, I., and de Wit, P. J. G. M. 2009. Fungal effector proteins. Annu. Rev. Phytopathol. 47:233-263.

Sweigard, J. A., Chumley, F. G., and Valent, B. 1992. Disruption of a Magnaporthe grisea cutinase gene. Mol. Gen. Genet. 232:183-190.

Tanabe, S., Okada, M., Jikumaru, Y., Yamane, H., Kaku, H., Shibuya, N., and Minami, E. 2006. Induction of resistance against rice blast fungus in rice plants treated with a potent elicitor, $N$-acetylchitooligosaccharide. Biosci. Biotechnol. Biochem. 70:1599-1605.

Tsuda, K., and Katagiri, F. 2010. Comparing signaling mechanisms engaged in pattern-triggered and effector-triggered immunity. Curr. Opin. Plant Biol. 13:459-465.

Tsuda, K., and Somssich, I. E. 2015. Transcriptional networks in plant immunity. New Phytol. 206:932-947.

Ueki, S., Lacroix, B., Krichevsky, A., Lazarowitz, S. G., and Citovsky, V. 2009. Functional transient genetic transformation of Arabidopsis leaves by biolistic bombardment. Nat. Protoc. 4:71-77.

Van Breusegem, F., and Dat, J. F. 2006. Reactive oxygen species in plant cell death. Plant Physiol. 141:384-390.

van Doorn, W. G. 2011. Classes of programmed cell death in plants, compared to those in animals. J. Exp. Bot. 62:4749-4761. 
Wang, Y., Kim, S. G., Wu, J., Kim, S. T., and Kang, K. Y. 2014. Differential proteome and secretome analysis during rice-pathogen interaction. Methods Mol. Biol. 1072:563-572.

Wu, J., Lee, D. Y., Wang, Y., Kim, S. T., Baek, S., Kim, S. G., and Kang, K. Y. 2014. Protein profiles secreted from phylloplane of rice leaves free from cytosolic proteins: Application to study riceMagnaporthe oryzae interactions. Physiol. Mol. Plant Pathol. 88: 28-35.

Yang, Y., Zhang, H., Li, G., Li, W., Wang, X., and Song, F. 2009. Ectopic expression of MgSM1, a Cerato-platanin family protein from Magnaporthe grisea, confers broad-spectrum disease resistance in Arabidopsis. Plant Biotechnol. J. 7:763-777.

Yoshimoto, K., Jikumaru, Y., Kamiya, Y., Kusano, M., Consonni, C., Panstruga, R., Ohsumi, Y., and Shirasu, K. 2009. Autophagy negatively regulates cell death by controlling NPR1-dependent salicylic acid signaling during senescence and the innate immune response in Arabidopsis. Plant Cell 21:2914-2927.

Zaparoli, G., Cabrera, O. G., Medrano, F. J., Tiburcio, R., Lacerda, G., and Pereira, G. G. 2009. Identification of a second family of genes in Moniliophthora perniciosa, the causal agent of witches' broom disease in cacao, encoding necrosis-inducing proteins similar to ceratoplatanins. Mycol. Res. 113:61-72.

\section{AUTHOR-RECOMMENDED INTERNET RESOURCE}

Magnaporthe comparative genomics database: http://www.broad.mit.edu/annotation/fungi/magnaporthe 